\title{
M2 macrophages are more resistant than M1 macrophages following radiation therapy in the context of glioblastoma
}

\author{
Marine M. Leblond ${ }^{1}$, Elodie A. Pérès ${ }^{1}$, Charly Helaine ${ }^{1}$, Aurélie N. Gérault ${ }^{1}$, Damien \\ Moulin ${ }^{1}$, Clément Anfray ${ }^{1}$, Didier Divoux ${ }^{1}$, Edwige Petit' ${ }^{1}$, Myriam Bernaudin ${ }^{1}$ and \\ Samuel Valable ${ }^{1}$ \\ ${ }^{1}$ Normandie Université, UNICAEN, CEA, CNRS, ISTCT/CERVOxy Group, 14000 Caen, France \\ Correspondence to: Samuel Valable, email: valable@cyceron.fr \\ Keywords: macrophages, irradiation, glioblastoma, radioresistance, phenotypic selection \\ Received: December 21, 2016 \\ Accepted: July 23, 2017 \\ Published: August 07, 2017 \\ Copyright: Leblond et al. This is an open-access article distributed under the terms of the Creative Commons Attribution License 3.0 \\ (CC BY 3.0), which permits unrestricted use, distribution, and reproduction in any medium, provided the original author and source \\ are credited.
}

\section{ABSTRACT}

In some highly inflammatory tumors, such as glioblastoma (GB), macrophages (MФ) represent the most abundant population of reactive cells. $M \Phi$, initially denoted as $M 0 M \Phi$, can be polarized into two further phenotypes: the antitumor M1 MФ, and the protumor M2 MФ. The three phenotypes can reside simultaneously in the tumor mass and various external factors may influence MФ polarization. Radiotherapy is a common modality of cancer treatment aiming to target tumor cells. However, the specific effects of $X$-ray radiation on the inflammatory cells are, so far, controversial and not fully understood. In the present investigation, we have first analyzed, in vivo, the effect of $X$-ray radiation on $M \Phi$ present in GB tumors. We have observed a decrease in MФ number paralleled by an increase in the proportion of M2 MФ. To understand this phenomenon, we then evaluated, in vitro, the effects of $X$-rays on the $M \Phi$ phenotypes and survival. We have found that $X$-ray radiation failed to modify the phenotype of the different МФ. However, M1 МФ were more sensitive to ionizing radiation than $M 2 M \Phi$, both in normoxia and in hypoxia, which could explain the in vivo observations. To conclude, M2 MФ are more radioresistant than M0 and M1 MФ and the present study allows us to propose that $X$-ray radiotherapy could contribute, along with other phenomena, to the increased density in the protumor M2 MФ in GB.

\section{INTRODUCTION}

Glioblastoma (GB) are the most frequent and aggressive form of the primary malignant brain tumors in adults [1]. Conventional therapy consists of surgery associated with X-ray radiotherapy $(5 \times 2$ Gy per week for 6 weeks, for a total dose of $60 \mathrm{~Gy}$ ) with concomitant and adjuvant chemotherapy based on temozolomide [2]. Despite this therapeutic arsenal, recurrence inevitably occurs and the median survival of GB patients remains around 15 months [3].

GB are highly heterogeneous tumors in which various cell types coexist, such as tumor cells, endothelial cells, fibroblasts and different cell types of the immune system [4]. Of all the different cell types colonizing
GB, macrophages $(\mathrm{M} \Phi)$ are the most abundant infiltrating immune cells and are named tumor associated macrophages (TAM) [5]. Circulating monocytes can migrate towards the tumor and once in the tissue, monocytes differentiate into $\mathrm{M} \Phi$, called $\mathrm{M} 0 \mathrm{M} \Phi$, under the influence of cytokines [6]. In GB, the myeloid population is the major player of the innate immune system and represents up to $30 \%$ of the tumor mass [7]. Interestingly, the number of $\mathrm{M} \Phi$ retrieved in the tumor is inversely correlated to the overall survival of GB patients [8].

Once differentiated, M0 M $\Phi$ exhibit a considerable degree of plasticity and can be polarized into two well established functional phenotypes, termed M1 and M2 MФ [9]. M1 MФ, characterized in part by the expression 
of the inducible type of nitric oxide synthase (iNOS), are classically activated $\mathrm{M} \Phi$ implicated in an antitumor activity, exemplified by their phagocytic properties and their capacity to activate the synthesis of pro-inflammatory cytokines [10]. In contradistinction, M2 MФ are essentially characterized by a potent arginase-1 (Arg1) activity and the CD206 marker. These activated M $\Phi$ are known to promote tumor development by tissue remodeling, cell proliferation, immunoregulation and angiogenesis [11]. As we reported recently, within the tumor mass, the three $\mathrm{M} \Phi$ phenotypes are observed with the predominance of the M0 and M1 phenotypes in the most oxygenated area of the tumor whereas the M2 M $\Phi$ are found in the hypoxic/necrotic areas [12]. Beyond its involvement in tumor growth, the $\mathrm{M} \Phi$ phenotype is also suspected to be associated with a poor response to GB treatments [8].

Ionizing radiations (IR), such as $\mathrm{X}$ - and $\gamma$-radiations, can also influence the tropism of $\mathrm{M} \Phi$ in the tumor by an increased production of chemokines at the origin of MФ migration. In support of the above, studies have demonstrated that irradiation promotes the recruitment of MФ in brain tumors approximately 20 days post-radiation [13] by increasing the stromal cell derived factor-1 (SDF1) production $[13,14]$.

With respect to the phenotype of $M \Phi$ following exposure to IR, an increase in M2 markers has been observed, in vivo, in various tumor types $[13,15,16]$, including GB [17]. Others studies have reported that radiation therapy can also increase M1 markers [18] while others failed to observe any change in cytokine production [19]. X-ray exposure also induces a local reoxygenation [20] which could in turn modulate the MФ phenotype [12].

Due to the controversial findings in the literature, it is necessary to clarify the $M \Phi$ response to irradiation. As of present, the effects of IR exposure on the three MФ phenotypes have never been analyzed in vitro and require investigations not only on the polarization of $\mathrm{M} \Phi$ but also on their fate.

A better understanding of the effects of X-rays on $\mathrm{M} \Phi$ phenotype is essential to tailor therapeutic approaches since attention has recently been focused on the role of TAM in the mechanisms of resistance to treatment [21]. Two main hypotheses may be advanced to elucidate as to whether irradiation influences the proportion of one phenotype compared to the others: i) X-ray exposure polarizes or re-educates $\mathrm{M} \Phi$; or ii) one phenotype is more sensitive to radiation-induced cell death than the others. To test these hypotheses, we have first evaluated, in vivo, the effect of IR on TAM present in GB. In a second stage, we have investigated, in vitro, whether $\mathrm{X}$-ray radiation induces a change in the phenotype of M0, M1 and M2 $\mathrm{M} \Phi$ or whether X-ray radiation is deleterious in the three different phenotypes. Cells were irradiated with either $2 \mathrm{~Gy}$ or $8 \mathrm{~Gy}$ of X-rays. 2Gy per day is a dose usually delivered in GB patients. However, as 2 Gy produces only modest cell death, 8Gy was also delivered to amplify any differences in the radiosensitivities of the different cell populations. Given the hypoxic nature of GB and that hypoxia represents a factor of poor prognosis and also influences inflammation [12], experiments were conducted under normoxic, moderate $\left(1 \% \mathrm{O}_{2}\right.$, the $\mathrm{O}_{2}$ level commonly found in GB) [22] and severe $\left(0.2 \% \mathrm{O}_{2}\right.$, the $\mathrm{O}_{2}$ level found around necrotic areas of GB) hypoxic conditions, to recapitulate the various oxygen level that are present in the tumor situation.

\section{RESULTS}

\section{$\mathrm{X}$-ray radiation induces a marked decrease in $М \Phi$ number but an increase in $\mathrm{M} 2 \mathrm{M \Phi}$ proportion in GB}

We first aimed to determine whether X-ray radiation could influence MФ present in GB. For that, GL261 GBbearing mice were exposed to X-rays 7 days after cells implantation. Early post-irradiation treated animals and their respective controls were euthanized 14 days after cells implantation ( 3 days after the last IR) and late postirradiation animals were euthanized 27 days after cells implantation (16 days after the last IR) (Figure 1). MФ were detected by CD68 immunostaining. $\mathrm{CD} 68^{+}$cells were observed in the tumor mass of both non-irradiated and irradiated mice (Figure 2A). In non-irradiated mice, the density of $\mathrm{CD}^{+} 8^{+}$cells present in the core of the tumor was about $29.5 \pm 6.5 \%$ of the tumor area. However, after $\mathrm{X}$-ray radiation, a significant decrease in $\mathrm{CD} 68^{+}$cells was observed. The density of CD $68^{+}$cells was $7.2 \pm 3.8 \%$ and $11.4 \pm 2.4 \%$ in the tumor mass early and late after $\mathrm{X}$-ray treatment, respectively. However, in the late postirradiation tumors, we can detect the presence of $\mathrm{CD}^{+} 8^{+}$ cells outside the tumor core (white arrows). This suggests that $\mathrm{CD} 68^{+}$cells start to be recruited within the tumor. We then evaluated the percentage of $\mathrm{M} 2 \mathrm{M} \Phi$ before and after IR by CD206 immunostaining (Figure 2B). While CD206 cells represented about $12.0 \pm 2.4 \%$ of the $\mathrm{CD} 68^{+}$cells in the non-irradiated group, it significantly increased to $50.7 \pm 5.3 \%$ and $49.9 \pm 6.1 \%$ in the tumor mass early and late after radiation, respectively, without any change in the absolute number of M2 MФ (Figure 2B).

These results indicate that $\mathrm{X}$-ray radiation decreases the number of $М \Phi$ but favors an enrichment in $\mathrm{M} 2$ phenotype in GB. We then asked the question, using in vitro experiments, whether the present observations were the result of a change in the $М \Phi$ phenotype after X-ray treatment or whether the difference was the results of preferential radio-sensitivity between $M \Phi$ phenotypes.

\section{$X$-ray radiation does not change the phenotype of MФ}

We then aimed to determine whether X-ray radiation could change the $\mathrm{M} \Phi$ phenotype in normoxic or hypoxic 
conditions. In vitro, M0, M1 and M2 MФ were cultured in $20 \%, 1 \%$ or $0.2 \% \mathrm{O}_{2}$ and cells were irradiated with a dose of $2 \mathrm{~Gy}$. From microscopic observation, no change at the morphological level was observed in any of the $M \Phi$ phenotypes after exposure to X-ray radiation in normoxia and in hypoxia (Figure 3A). To confirm this observation, the NO production (used as a marker of M1 MФ) and the Arg1 activity (used as a marker of M2 MФ) were analyzed $24 \mathrm{~h}$ and $72 \mathrm{~h}$ post-radiation, as we previously provided evidence that theses markers are robust markers to assess the phenotype of bone marrow derived MФ [12]. As we published [12], NO was difficult to detect in M0 and M2 $\mathrm{M} \Phi$ both in normoxia and hypoxia. In contrast, NO was easily detectable in M1 M $\Phi$ and the production decreased in hypoxia (Figure 3B). For all three phenotypes, X-ray radiation did not change NO production (Figure $3 \mathrm{~B}$ ). In parallel, Arg1 activity was weak in M0 and M1 MФ in normoxia but was increased in both phenotypes when cultured under hypoxic conditions. There was a marked production of Arg1 in M2 MФ in normoxia and, as expected, its activity was reinforced in hypoxia (Figure 3C) [12]. However, for the three phenotypes, X-ray radiation did not change the level of Arg1 activity either in normoxia or in hypoxia (Figure 3C). These results indicate that, in these experimental conditions, IR does not provoke direct changes in $M \Phi$ phenotypes under both normoxic and hypoxic conditions. Similar results were obtained with a high dose irradiation (8Gy) (data not shown).

\section{M0 and M1 MФ are more sensitive to X-ray radiation than M2 MФ}

The radiosensitivity of $\mathrm{M} \Phi$ to X-rays was then evaluated by quantifying the cell number at different times post-radiation $(2 \mathrm{~h}, 24 \mathrm{~h}$ and $72 \mathrm{~h}$ ) in $20 \%, 1 \%$ or $0.2 \%$ $\mathrm{O}_{2}$ (Figure 4A). In the $20 \% \mathrm{O}_{2}$ condition (Figure 4Aa), the kinetic curves of M0 and M1 MФ were significantly different from their respective control; an effect which was not observed for the M2 MФ. The difference between kinetic curves of M0 and M1 M $\Phi$ numbers was not significant while both curves were significantly different from the M2 M $\Phi$ population decrease. At $72 \mathrm{~h}$ postradiation, only $35.6 \pm 5.8 \%$ of $\mathrm{M} 0 \mathrm{M \Phi}$ and $57.3 \pm 9.1 \%$ of M1 M $\Phi$ were viable while about $81.9 \pm 4.4 \%$ of M2 MФ were still detected ( $<<0.001$ vs M0 and M1 MФ). The changes in M0 and M1 MФ survival, compared to M2 MФ, were not due to a greater M2 MФ proliferation (Supplementary Figure 1) but rather to a preferential cell death of M0 and M1 MФ. Similar results were observed when the three phenotypes were irradiated with a dose of 8Gy (Supplementary Figure 2A). Furthermore, the decrease in M1 number following radiation was not influenced by hypoxia $\left(1 \%\right.$ and $0.2 \% \mathrm{O}_{2}$ ) (Figure $4 \mathrm{Ab}$ and $4 \mathrm{Ac}$ ). Indeed, the number of irradiated M1 MФ were significantly reduced in all conditions, whatever the level of oxygenation, compared to non-irradiated M1 MФ (at $72 \mathrm{~h}$ post-radiation, only $50.3 \pm 6.1 \%$ and $47.3 \pm 6.5 \%$ of $\mathrm{M} 1$ $\mathrm{M} \Phi$ were still viable in $1 \%$ and $0.2 \% \mathrm{O}_{2}$, respectively). For M2 MФ, all hypoxic conditions remained non-significant relative to non-irradiated conditions $(85.4 \pm 11.7 \%$ and $92.9 \pm 6.5 \%$ of $\mathrm{M} 2 \mathrm{M} \Phi$ were viable in $1 \%$ and $0.2 \% \mathrm{O}_{2}$, respectively, $72 \mathrm{~h}$ post-irradiation) (Figure $4 \mathrm{Ab}$ and $4 \mathrm{Ac}$ ). However, M0 MФ appeared less sensitive to IR when they were cultured in severe hypoxia $\left(0.2 \% \mathrm{O}_{2}\right)$ since non-significant changes in cell survival were observed relative to $\mathrm{M} 0$ non-irradiated (at $72 \mathrm{~h}$ post-irradiation, $88.5 \pm 15.2 \%$ of $\mathrm{M} 0 \mathrm{M} \Phi$ were viable in $0.2 \% \mathrm{O}_{2}$ compared to $67.6 \pm 7.6 \%$ in $1 \% \mathrm{O}_{2}$ ) (Figure $4 \mathrm{Ac}$ ). Hence, a hypoxiadependent radioresistance was only highlighted for M0 MФ while M2 MФ remained resistant whatever oxygen concentration.

Cell death in normoxia in M0 and M1 MФ was then confirmed by cell cycle studies performed by flow cytometry (Figure 4B). Only about $10 \%$ of non-irradiated M0 and M1 MФ were found in the sub-G1 phase of the cell cycle, the cycle phase corresponding to cells with a

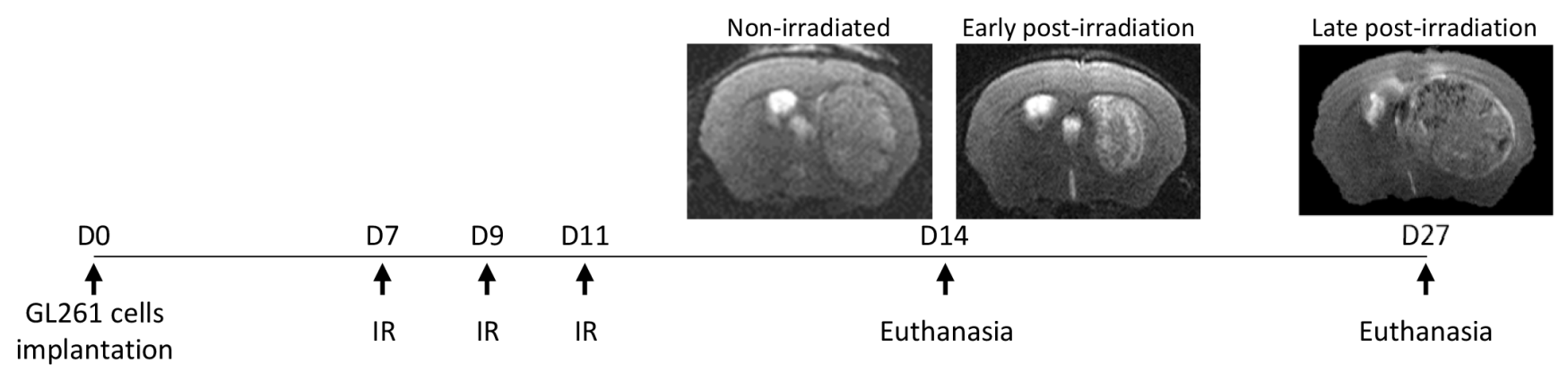

Figure 1: Experimental protocol of the GL261 glioma model with the representative MRI of the non-irradiated, early post-irradiation and late post-irradiation animals. Non-irradiated and early post-irradiation tumors were both arrested 14 days after the GL261 cells implantation (non-irradiated tumor volume $\approx 40 \mathrm{~mm}^{3}$; early post-irradiation tumor volume $\approx 10 \mathrm{~mm}^{3}$ ) to match in time and just before the complete regression of the irradiated tumors. Late post-irradiation tumors, corresponding to recurrence, were arrested when the tumor reached $50 \mathrm{~mm}^{3}$. This time point does not have non-irradiated tumors because the control tumors developed too rapidly without any treatments. 


\section{A}
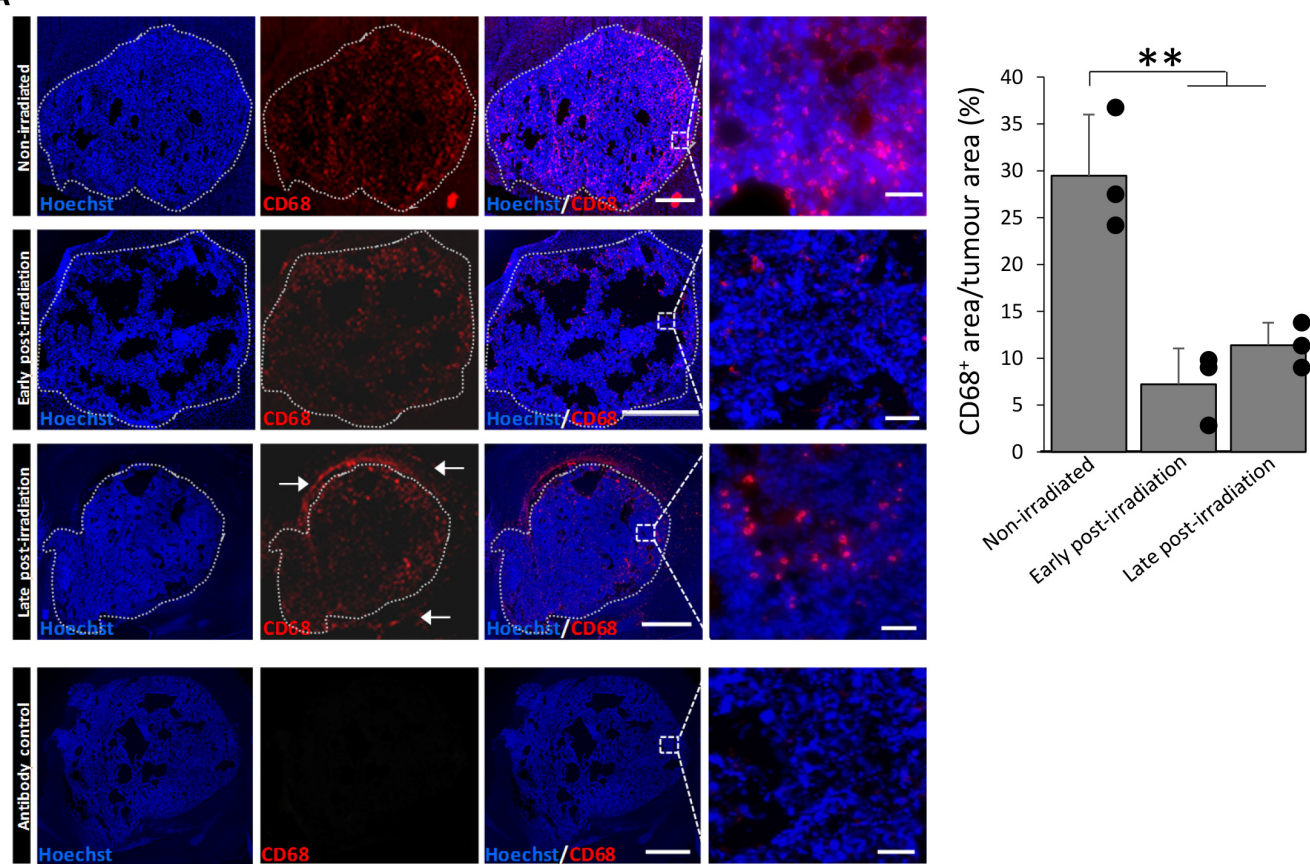

B
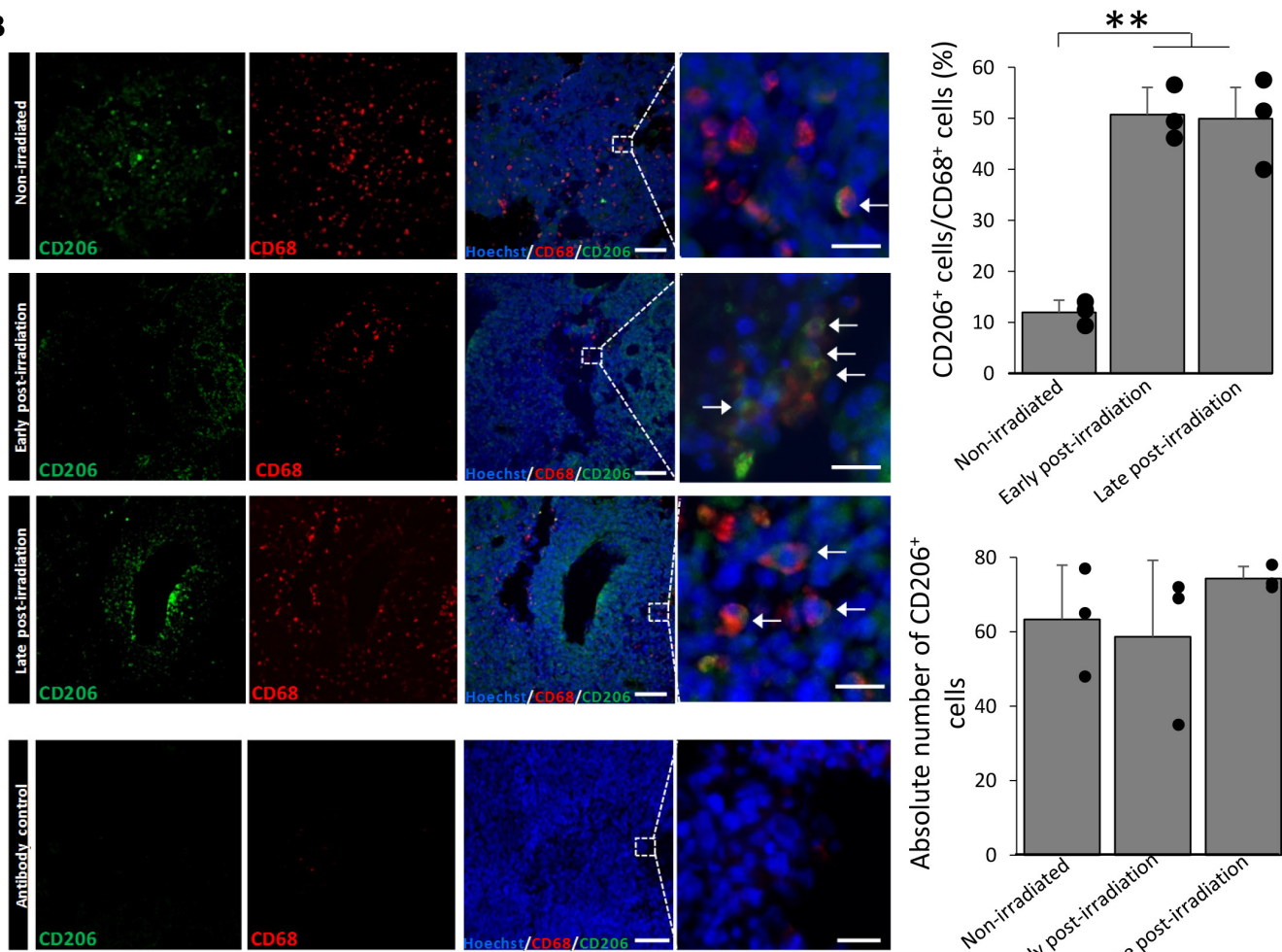

Figure 2: X-ray radiation increases the proportion of M2 MФ in the GL261 GB model. (A) Representative CD68 (red) and Hoechst 33342 (blue) immunofluorescent images of the GL261 orthotopic tumor model and the quantification of the percentage of $\mathrm{CD}^{+} 8^{+}$pixels compared to the tumor area before and early ( 3 days) or late (16 days) after X-Ray treatment. Scale bars $=1000 \mu \mathrm{m}$ or $50 \mu \mathrm{m}$ for low or high magnification, respectively. Doted lines delimit the tumor areas from the brain tissue and they correspond to the areas of quantification. Black areas correspond to necrotic tissues and they are excluded from the quantification. White arrows indicate the CD68 ${ }^{+}$ cells outside the tumor and which were not quantified. Antibody control images were used to confirm the specificity of the CD68 signal. (B) Representative CD206 (green), CD68 (red) and Hoechst 33342 (blue) immunofluorescent images of the GL261 orthotopic tumor and the quantification of $\mathrm{CD} 206^{+}$cells compared to $\mathrm{CD} 68^{+}$cells before and early ( 3 days) or late ( 16 days) after X-ray treatment. Scale bars $=100 \mu \mathrm{m}$ for low magnification and scale bars $=20 \mu \mathrm{m}$ for high magnification. Antibody control images were used to confirm the specificity of the CD206 and CD68 signals. Three sections for each animal and 3 animals per group were used ( $\mathrm{n}=9$ images per group, each point represent the mean of the 3 images), statistical significance was achieved when $\mathrm{p}<0.01(* *)$. 
DNA quantity inferior to $2 \mathrm{n}$, which could be a reflection of cell death. However, a significant proportion of M0 $(34.5 \pm 3.9 \%)$ and M1 (41.2 $\pm 7.5 \%) \mathrm{M} \Phi$ was found in the sub-G1 phase of the cell cycle $72 \mathrm{~h}$ after radiation. It could be noted that these changes in sub-G1 phase after irradiation is to the detriment of M0 and M1 MФ proportion in G0/G1 phase. Concerning M2 MФ, the cytometry profile confirmed the absence of an effect of IR on the cell cycle. Similar results were obtained with a high dose irradiation (8Gy) (Supplementary Figure 2B).

A
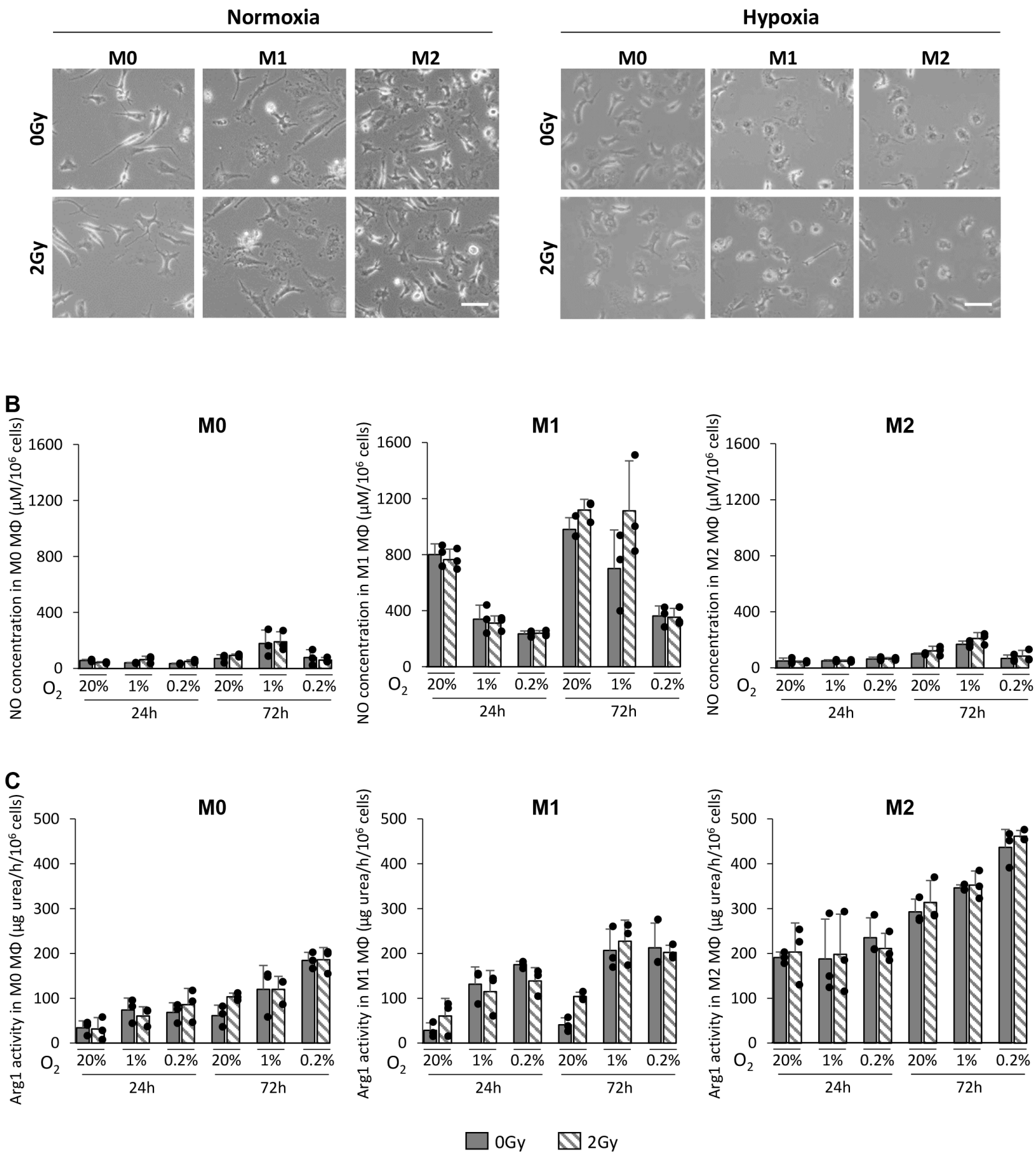

Figure 3: X-ray radiation does not change the phenotype of МФ in vitro. (A) Representative phase contrast microscopy images of M0, M1 and M2 MФ 24h after $0 \mathrm{~Gy}$ and $2 \mathrm{~Gy}$ radiation in $20 \%$ (normoxia) or $0.2 \% \mathrm{O}_{2}$ (hypoxia). Scale bar=20 $\mu \mathrm{m}$. (B) $\mathrm{NO}$ concentration ( $\mu \mathrm{M}$ per $10^{6}$ cells) in M0, M1 and M2 MФ $24 \mathrm{~h}$ and $72 \mathrm{~h}$ after 0 Gy and $2 \mathrm{~Gy}$ in $20 \%, 1 \%$ and $0.2 \% \mathrm{O}_{2}$. (C) Arg1 activity ( $\mu$ g urea/h per $10^{6}$ cells) in M0, M1 and M2 MФ 24h and 72h after $0 \mathrm{~Gy}$ and $2 \mathrm{~Gy}$ radiation in 20\%, $1 \%$ and $0.2 \% \mathrm{O}$. $\mathrm{n}=3$ different experiments per condition. 
M0 and M1 MФ cell death were also confirmed by the increase in cell debris after IR (Supplementary Figure 3). These results support the hypothesis that M2 MФ are more resistant to $\mathrm{X}$-ray radiation compared to the $\mathrm{M} 0$ and M1 MФ phenotypes. Given that 2Gy and $8 \mathrm{~Gy}$ irradiations have similar effects on $\mathrm{M} \Phi$ survival, only the results with the dose of $2 \mathrm{~Gy}$ are presented thereafter.

\section{X-ray radiation induces similar DNA double- strand breaks between the different MФ phenotype}

To decipher the mechanisms involved in the selective death of M0 and M1 M $\Phi$, we analyzed the formation of DNA double strand breaks (DSBs) after irradiation. We evaluated whether M0, M1 and M2 $\mathrm{M} \Phi$ respond to X-ray radiation in a similar way, both in normoxia and hypoxia. To evaluate DNA DSBs in the three MФ phenotypes, $\gamma \mathrm{H} 2 \mathrm{AX}$ immunostaining was performed at different time post-radiation $(2 \mathrm{~h}, 24 \mathrm{~h}$ and 72h) (Figure 5A) and the percentage of $\gamma \mathrm{H} 2 \mathrm{AX}^{+}$cells (i.e. cells with more than 10 foci) was quantified (Figure 5B). Under normoxia, for the three $М \Phi$ phenotypes, the percentage of $\gamma \mathrm{H} 2 \mathrm{AX}^{+}$cells was maximal $2 \mathrm{~h}$ after $2 \mathrm{~Gy}$ $\mathrm{X}$-ray radiation $(24.8 \pm 7.4 \%$ in $\mathrm{M} 0 \mathrm{M} \Phi, 22.9 \pm 13.1 \%$ in M1 MФ and $22.8 \pm 3.17 \%$ in M2 MФ) and significantly different from the respective controls (0Gy, $0.6 \pm 0.5 \%$ of cells with DNA DSBs) (Figure 5Ba). While M1 M $\Phi$
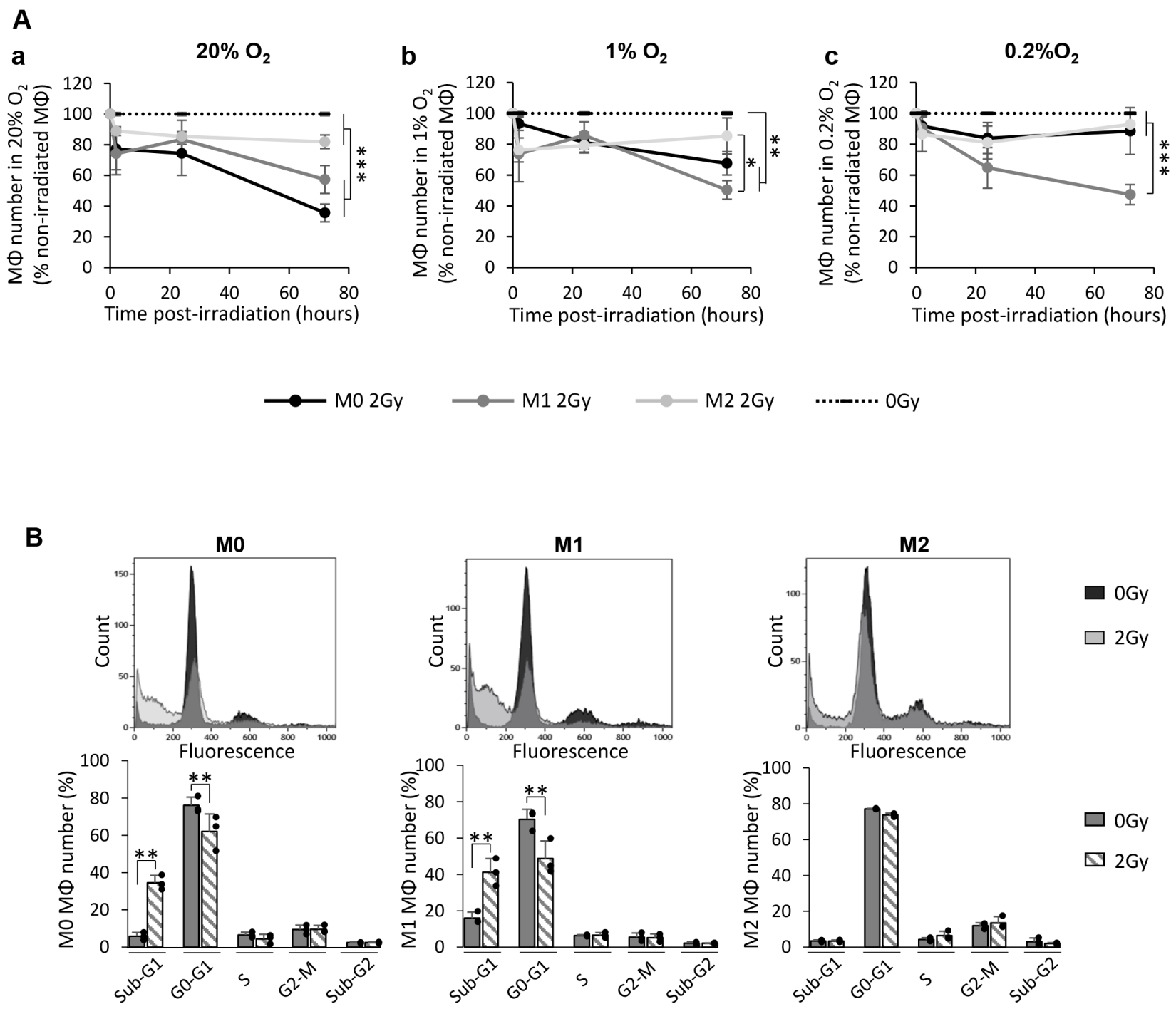

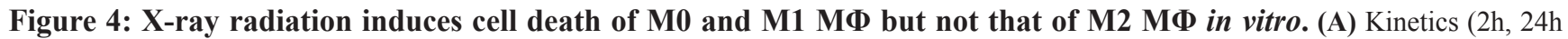
and $72 \mathrm{~h}$ post-radiation) of M0, M1 and M2 MФ cell numbers expressed as a percentage of control (0Gy) after 2Gy in $20 \%$ (a), $1 \%$ (b) or $0.2 \% \mathrm{O}_{2}(\mathrm{c})$. Dotted lines correspond to non-irradiated M0, M1 and M2 MФ. n=3 distinct experiments for each time point and each MФ phenotype. Tukey's HSD test after significant one factor ANOVA (group) was used. Statistical significance was achieved when $\mathrm{p}<0.05\left(^{*}\right)$, $\mathrm{p}<0.01(* *)$ and $\mathrm{p}<0.001(* * *)$. (B) Cell cycle profiles and quantification of the cell distribution in different phases for M0, M1 and M2 MФ $72 \mathrm{~h}$ after $0 \mathrm{~Gy}$ and $2 \mathrm{~Gy}$ in $20 \% \mathrm{O}_{2} . \mathrm{n}=3$ different experiments per condition. Statistical significance was $\mathrm{p}<0.01(* *)$. 
present more $\gamma \mathrm{H} 2 \mathrm{AX}^{+}$cells than M0 and M2 MФ 24h after IR, this difference is not significant $(\mathrm{p}=0.5717$ between M1 and M0 M $\Phi$; $\mathrm{p}=0.3369$ between M1 and M2 $\mathrm{M \Phi ).} \mathrm{Moreover,} \mathrm{for} \mathrm{the} \mathrm{three} \mathrm{phenotypes,} \mathrm{the} \mathrm{number} \mathrm{of}$ $\gamma \mathrm{H} 2 \mathrm{AX}^{+}$cells decreases as a function of time to reach the level of the control cells $72 \mathrm{~h}$ post-radiation. These results suggest that the genotoxicity induced by X-rays is similar between the three $\mathrm{M} \Phi$ phenotypes and that they can repair DNA DSBs in normoxia.

In presence of $1 \% \mathrm{O}_{2}$ (Figure $5 \mathrm{Bb}$ ), $\mathrm{M} 0 \mathrm{M} \Phi$ present less $\gamma \mathrm{H} 2 \mathrm{AX}^{+}$cells $(12.9 \pm 6.9 \%)$ than in the $20 \% \mathrm{O}_{2}$ condition but the difference is still significantly different from the control. M2 M $\Phi$ did not present significant number of $\gamma \mathrm{H} 2 \mathrm{AX}^{+}$cells $(10.5 \pm 4.7 \%)$ compared to control.
However, the formation of DNA DSBs in M1 MФ was not influenced by moderate hypoxia $(23.2 \pm 8.2 \%$ of cells $)$ and the kinetic curve of M1 MФ was significantly different from the ones of M0 and M2 MФ. This phenomenon was more pronounced at $0.2 \% \mathrm{O}_{2}$ (Figure $5 \mathrm{Bc}$ ). At $0.2 \%$ $\mathrm{O}_{2}$, the formation of DSBs was almost absent in M0 MФ and significantly different from the $20 \% \mathrm{O}_{2}$ condition $(p=0.0317)$. These results suggest that in hypoxia, M1

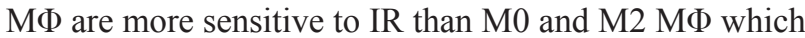
present an important hypoxia-induced radioresistance.

To further elucidate the more pronounced radiosensitivity of $\mathrm{M} 0$ and $\mathrm{M} 1 \mathrm{M} \Phi$ than $\mathrm{M} 2 \mathrm{M} \Phi$ (Figure 4), we then focused on radio-induced cell death by studying apoptosis and mitotic catastrophe.
A

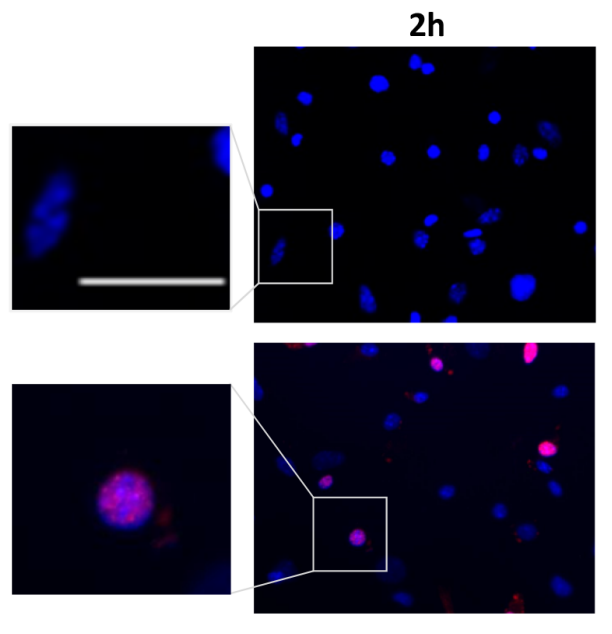

$24 h$
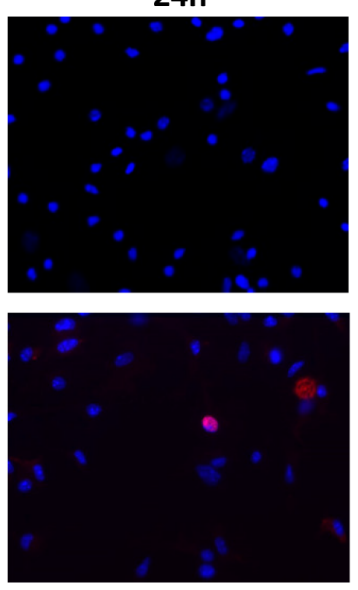

$72 \mathrm{~h}$

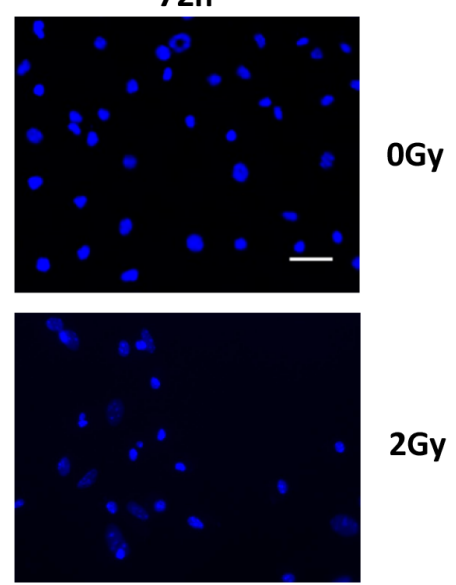

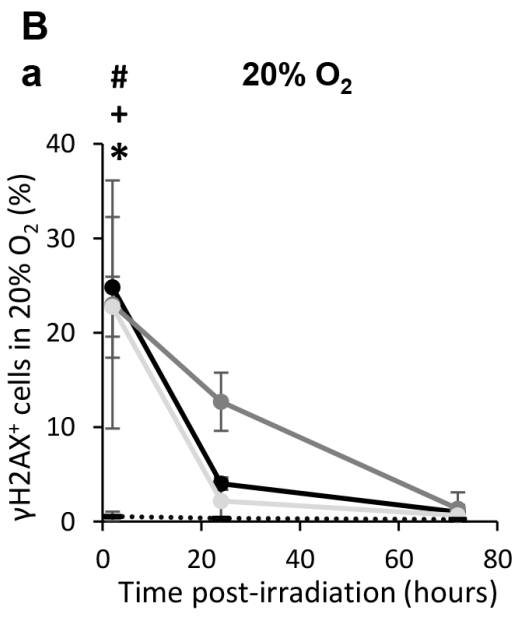

b

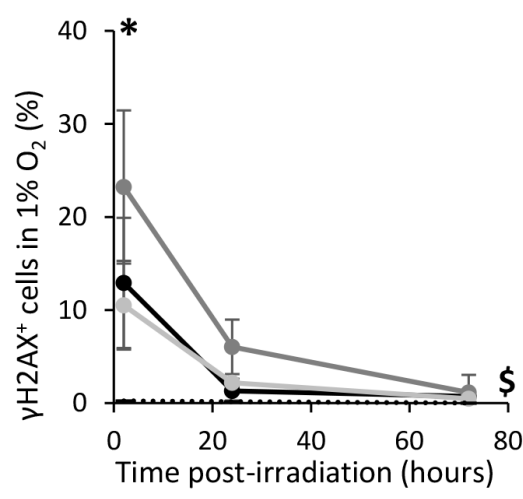

C

$0.2 \% \mathrm{O}_{2}$

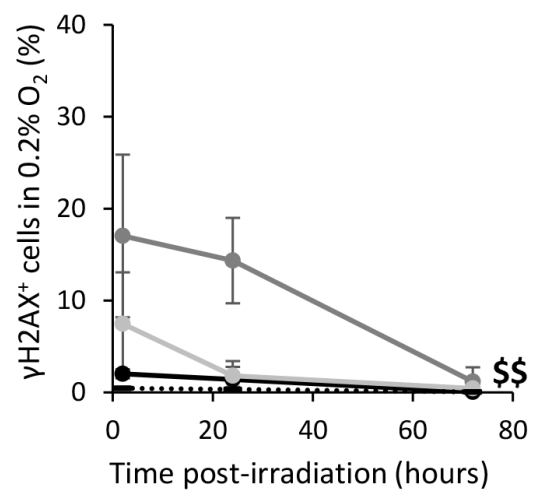

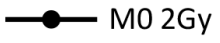
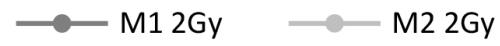

OGy

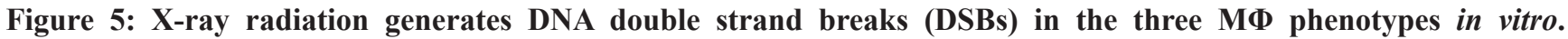
(A) Representative $\gamma \mathrm{H} 2 \mathrm{AX}$ and Hoechst 33342 immunofluorescence images of M0 MФ 2h, 24h and 72h after 0Gy and 2Gy radiation in $20 \% \mathrm{O}_{2}$. Scale bars $=20 \mu \mathrm{m}$. (B) Kinetics $\left(2 \mathrm{~h}, 24 \mathrm{~h}\right.$ and $72 \mathrm{~h}$ post-radiation) of DNA DSBs $\left(\gamma \mathrm{H} 2 \mathrm{AX}{ }^{+}\right.$cells) on M0, M1 and M2 M $\Phi$ after $2 \mathrm{~Gy}$ in $20 \%$ (a), $1 \%$ (b) and $0.2 \% \mathrm{O}_{2}$ (c). Dotted lines correspond to the mean of $\gamma \mathrm{H} 2 \mathrm{AX}^{+}$cells in non-irradiated M0, M1 and M2 M $\mathrm{n}=3$ experiments for each time point and each MФ phenotype. Tukey's HSD test after significant one factor (group) or two factors ANOVA (time and group) were used. p<0.05(*) M0 2Gy vs M0 0Gy, p<0.05(\#) M1 2Gy vs M1 0Gy and p<0.05(+) M2 2Gy vs M2 0Gy only 2h post-radiation. $\mathrm{p}<0.05(\$)$ and $\mathrm{p}<0.01(\$ \$) \mathrm{M} 1$ kinetic curve vs M1 0Gy, M0 2Gy and M2 2Gy kinetics curves. 
A
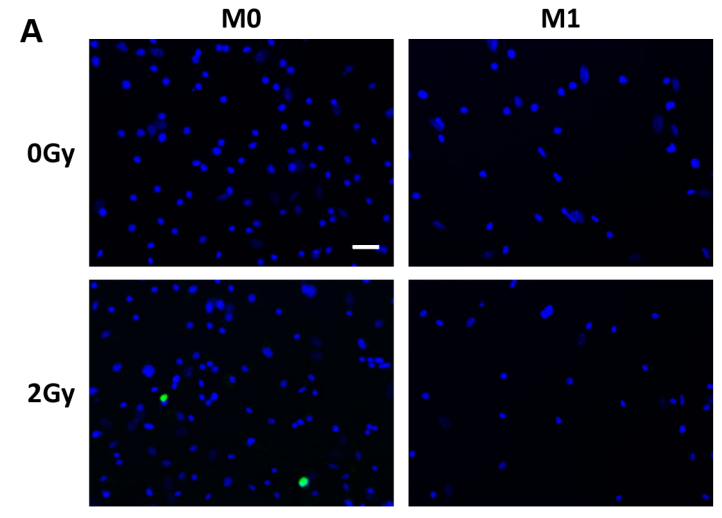

M1
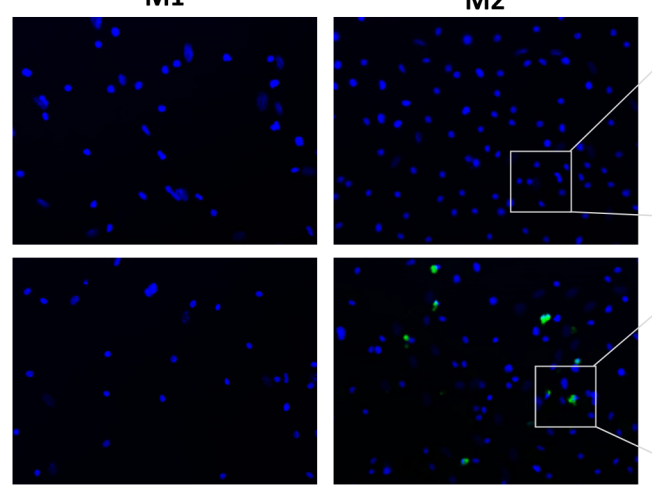

M2
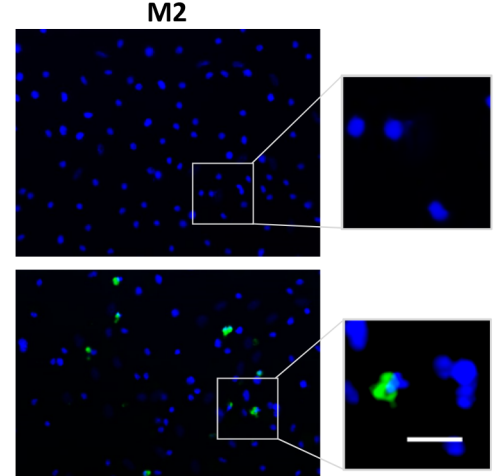

\section{B}
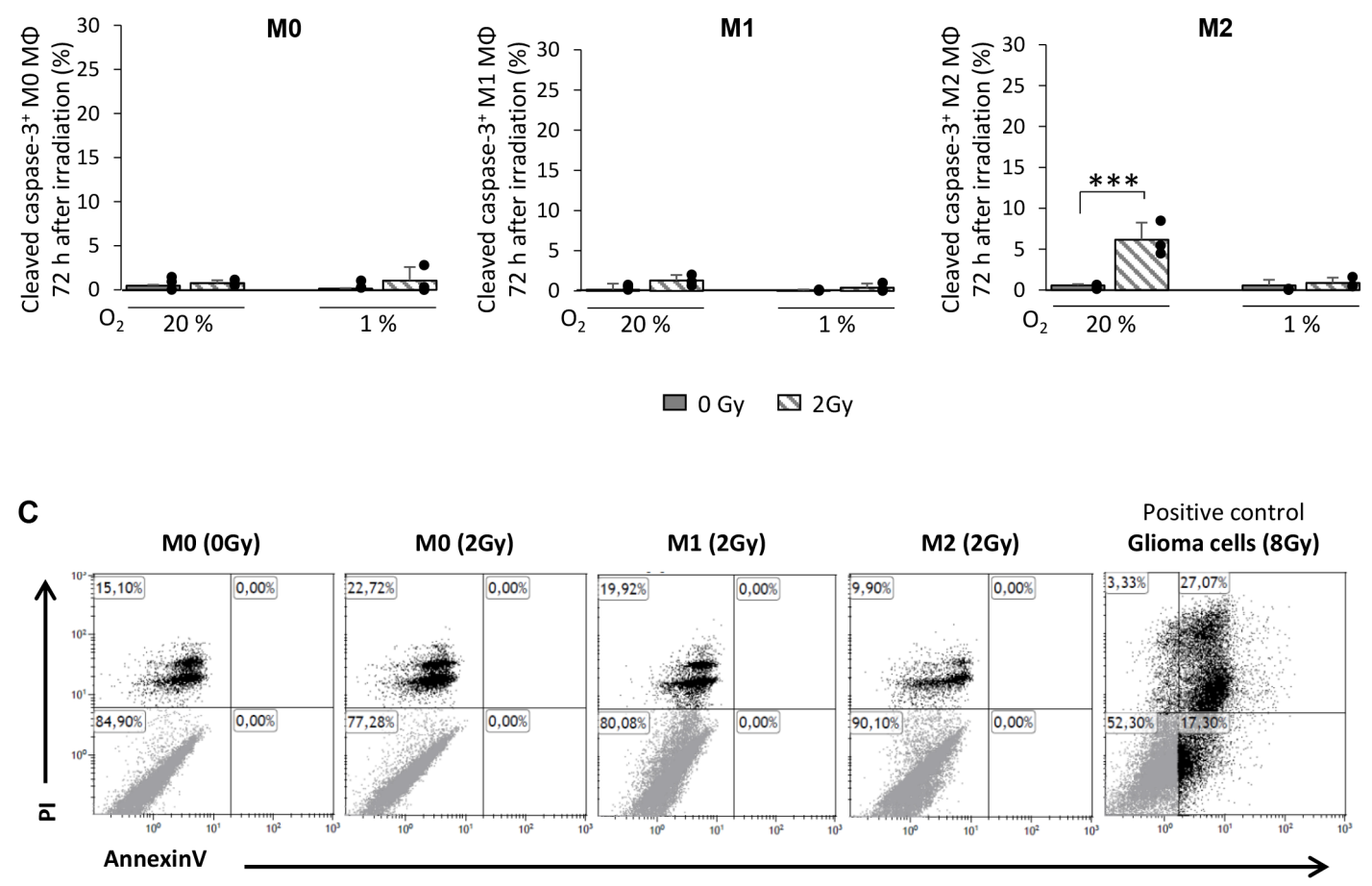

D

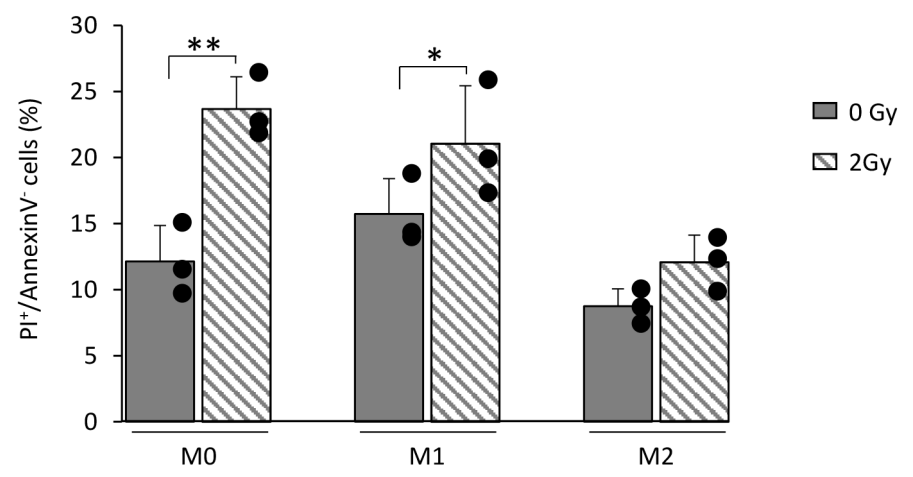

Figure 6: X-ray radiation fails to give rise to apoptosis in M0 and M1 MФ in vitro. (A) Representative cleaved-caspase-3

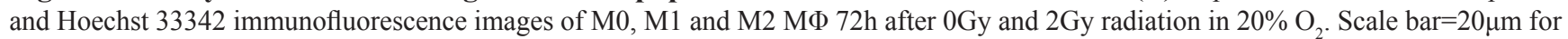
low magnification and scale bar $=10 \mu \mathrm{m}$ for high magnification. (B) Quantification of cleaved-caspase-3 on M0, M1 and M2 M $\Phi$ 72h postradiation (0Gy and $2 \mathrm{~Gy}$ ) in $20 \%$ and $1 \% \mathrm{O}_{2} \cdot \mathrm{n}=3$ experiments per condition. Statistical significance was seen with the irradiated $\mathrm{M} 2 \mathrm{M} \Phi$ $[\mathrm{p}<0.001(* * *)]$, otherwise no significant changes were noted. (C) Representative propidium iodide (PI)/AnnexinV flow cytometry profiles

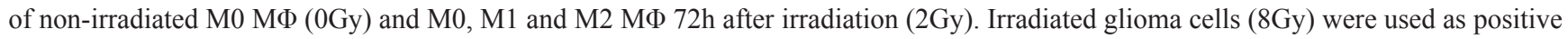
control for AnnexinV staining. (D) Quantification of $\mathrm{IP}^{+} / A n n e x i n V$ cells in M0, M1 and M2 MФ 72h after 0Gy and 2Gy radiation. $\mathrm{n}=3$ different experiments per condition. Statistical significance was achieved when $\mathrm{p}<0.05(*)$ and $\mathrm{p}<0.01(* *)$. 


\section{M0 and M1 МФ do not undergo apoptosis but manifest mitotic catastrophe after X-ray radiation}

According to the cell cycle profiles of M0 and M1 M $\Phi$ after X-rays (Figure 4B), we first posed the question whether the increase in sub-G1 phase is an index of apoptosis. We analyzed the activation of the cleaved form of caspase- 3 in the three $M \Phi$ phenotypes $72 \mathrm{~h}$ postradiation (Figure 6A). M0 and M1 M $\Phi$ failed to show a difference in the number of cleaved caspase- $3^{+}$cells after irradiation compared to control cells. However, a small population of M2 MФ (7.2 $\pm 2.3 \%)$ showed a cleaved caspase- $3^{+}$after radiation but only when the cells were cultured in $20 \% \mathrm{O}_{2}$ (Figure 6B). To further reinforce this result, Propidium Iodide (PI)/AnnexinV flow cytometry was performed on the three M $\Phi$ phenotypes (Figure 6C). No Annexin $V^{+}$cells were detected following irradiation whatever the phenotype studied, supporting the absence of apoptotic death after IR. Increased PI staining in M0 and M1 MФ is indeed in favor of a radio-induced mitotic catastrophe (Figure 6C and 6D).

To confirm the radio-induced mitotic catastrophe in $\mathrm{M} 0$ and $\mathrm{M} 1 \mathrm{M} \Phi$, we analyzed the formation of micronuclei (MN), as a reflection of aneuploidy following genomic instabilities [23] (Figure 7A). M0, M1 and M2 $\mathrm{M} \Phi$ were irradiated in $20 \%, 1 \%$ and $0.2 \% \mathrm{O}_{2}$ and the $\mathrm{MN}$ were counted at different times post-radiation $(2 \mathrm{~h}, 24 \mathrm{~h}$ and 72h) (Figure 7B). At 72h post-radiation, IR resulted in a significant increase in the percentage of MN positive cells (i.e. cells with at least one $\mathrm{MN}$ ) for both $\mathrm{M} 0$ and $\mathrm{M} 1 \mathrm{M} \Phi$

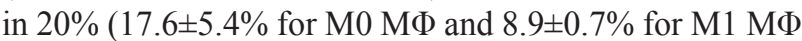

A
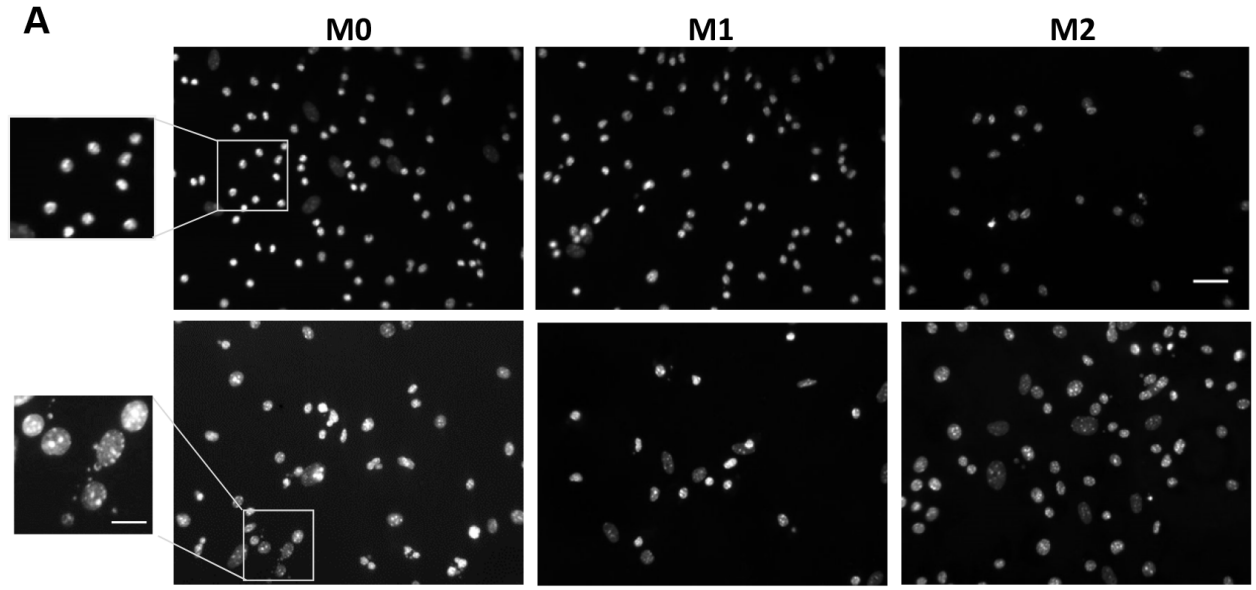

OGy

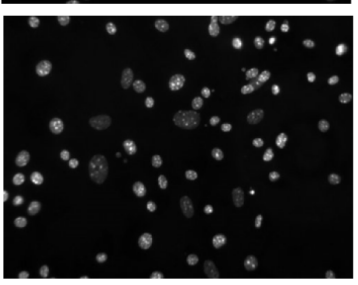

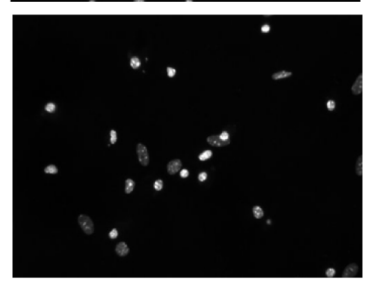

b

$20 \% \mathrm{O}_{2}$

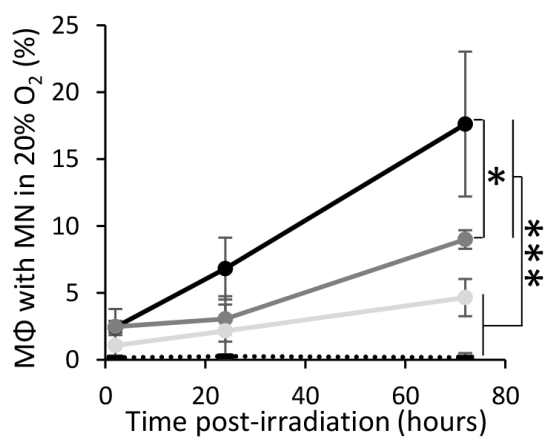

$\longrightarrow \mathrm{MO} 2 \mathrm{~Gy}$

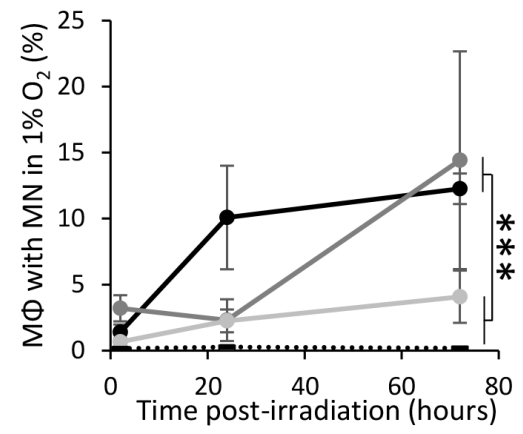

c

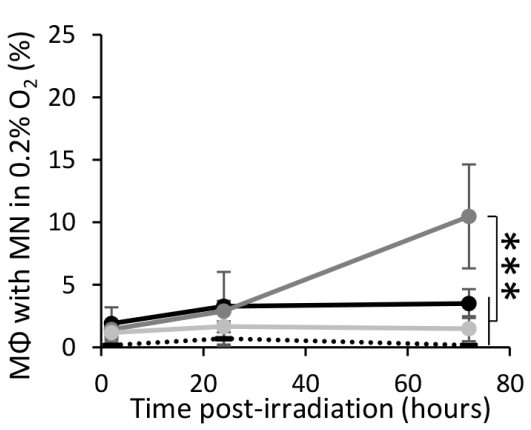

OGY

Figure 7: X-ray radiation induces the mitotic catastrophe in M0 and M1 MФ in vitro. (A) Representative Hoechst 33342 immunofluorescence images of M0, M1 and M2 MФ 72h after $0 \mathrm{~Gy}$ and $2 \mathrm{~Gy}$ radiation in $20 \% \mathrm{O}_{2}$. Scale bar=20 $\mu \mathrm{m}$ for low magnification and scale bar $=10 \mu \mathrm{m}$ for high magnification. (B) Kinetics (2h, 24h and 72h post-radiation) of percentage of M0, M1 and M2 M $\Phi$ with micronuclei $(\mathrm{MN})$ after $2 \mathrm{~Gy}$ radiation in $20 \%$ (a), $1 \%$ (b) and $0.2 \% \mathrm{O}_{2}$ (c). Dotted lines correspond to the mean of cells with $\mathrm{MN}$ in nonirradiated M0, M1 and M2 MФ. $\mathrm{n}=3$ experiments for each time point and each condition. Tukey's HSD test after significant one factor ANOVA (group) was used. Statistical significance were $p<0.05(*)$ and $p<0.001(* * *)$, otherwise it was not significant. 
with $\mathrm{MN}$ ) (Figure $7 \mathrm{Ba}$ ) and $1 \% \mathrm{O}_{2}(12.3 \pm 1.1 \%$ for $\mathrm{M} 0$

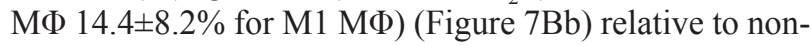
irradiated cells. M2 MФ presented only $4.6 \pm 1.4 \%$ of cells with $\mathrm{MN}$ at $20 \% \mathrm{O}_{2}$ and $4.0 \pm 1.9 \%$ at $1 \% \mathrm{O}_{2}$, differences which were not significantly different from control cells (Figure $7 \mathrm{Ba}$ and $7 \mathrm{Bb}$ ). Interestingly and in line with previous results concerning the cell number, in M0 MФ, the radiation-induced $\mathrm{MN}$ formation was significantly less when the cells were cultured at $0.2 \% \mathrm{O}_{2}$ compared to $20 \%$ and $1 \% \mathrm{O}_{2}$ (Figure $7 \mathrm{Bc}$ ). However, M1 MФ still present $\mathrm{MN}$ formation $72 \mathrm{~h}$ post-irradiation at $0.2 \% \mathrm{O}_{2}(10.5 \pm 4.1 \%$ of cells with $\mathrm{MN}$ ) which is significantly different to respective control, and irradiated M0 and M2 MФ (Figure $7 \mathrm{Bc})$.

Altogether, these results indicate that M0 and M1 MФ do not undergo apoptosis following IR but rather radio-induced mitotic catastrophe. Moreover, it seems that M1 MФ is the most radiosensitive phenotype since these cells react similarly in both normoxia and in hypoxia.

\section{DISCUSSION}

$M \Phi$, the most abundant inflammatory cells found in GB [5], promote tumor development and represent a negative prognostic factor [24] notably because of the presence of the M2 phenotype [8]. However, the impact of conventional therapies, and particularly radiotherapy, on these cells is still not well understood. We have shown, in vivo, that radiotherapy with $\mathrm{X}$-ray exposure induces a loss of $\mathrm{M} \Phi$ present in GB. Interestingly, we have demonstrated that the proportion of M2 MФ (CD206 cells) relative to total $\mathrm{M} \Phi\left(\mathrm{CD}^{+} 8^{+}\right.$cells $)$was increased after IR. In vitro, we have confirmed that these changes are not due to a modification of the $М \Phi$ phenotype but rather to an increase in the $\mathrm{M} 2 \mathrm{M} \Phi$ population by preferentially inducing cell death of M0 and M1 M $\Phi$. In contrast to M0 and $\mathrm{M} 1 \mathrm{M} \Phi, \mathrm{M} 2 \mathrm{M} \Phi$ are less sensitive to irradiation.

We describe a decrease in $М \Phi$ number occurring early after IR as already mentioned in prostate cancer [17]. In the late time, the presence of $\mathrm{CD}^{+} 8^{+}$cells outside the tumor core was also observed suggesting that $\mathrm{CD} 68^{+}$ cells start to be recruited within the GB tumor in good agreement with the literature in GB $[13,27]$ and other tumors [16].

Concerning the $М \Phi$ phenotype, several controversial investigations have analyzed the impact of IR on MФ phenotype in vivo. For instance, an increase in M1 MФ markers was noted after radiation therapy [25-27] while others have reported an increase in M2 M $\Phi$ markers [15, 28, 29]. Moreover, a lack of effect of radiation on cytokine production was observed in vitro $[19,30]$. In contradistinction, we have shown that $\mathrm{M} \Phi$ in GB change their morphology and an increase in M2 marker is observed after IR, as previously described [17]. However, in this study, we have found that X-ray treatment increased the M2 MФ proportion in a GB model of recurrence. Two main hypotheses have been proposed to elucidate how IR influences MФ: i) X-ray exposure alters the phenotype of $\mathrm{M} \Phi$; or ii) one phenotype is more resistant to radioinduced cell death than the others.

Within the context of these two hypotheses, we have demonstrated in vitro that the phenotype of $М \Phi$ remained unchanged with X-ray radiation. NO and Arg1 were used as we previously provided evidence that theses markers are sensitive markers of bone marrow derived MФ [12]. These results led us to postulate that the sensitivity to $\mathrm{X}$-ray radiation could be different depending on the $\mathrm{M} \Phi$ phenotype.

Controversial and contradictory studies related to the impact of radiation therapy on $М \Phi$ fate have been published. While numerous studies have described MФ as a radioresistant cell type $[19,30]$, other studies have found either an increase in $\mathrm{M} \Phi$ in the tumor following X-ray or a decrease $[15,18]$. However, no single investigation has differentiated the response of the three distinct phenotypes to direct radiation. In the present study, we have found that $\mathrm{M} 0$ and $\mathrm{M} 1 \mathrm{M} \Phi$ were more sensitive to radiation than M2 МФ.

An important decrease in the number of M0 and M1 MФ was observed in vitro in $20 \% \mathrm{O}_{2}$, as these phenotypes are usually found in oxygenated areas of GB [12], following radiation. This observation was also noticed when the cells were cultured under moderate hypoxic condition $\left(1 \% \mathrm{O}_{2}\right)$. Although we have shown that M0 and $\mathrm{M} 1 \mathrm{M} \Phi$ are able to repair DNA DSBs, their number also decreased post-radiation. This profile might suggest that M0 and M1 M $\Phi$ misrepair DNA DSBs leading to certain genomic instabilities. Both nuclear fragmentation (sub-G1 phase) and MN formation along with the absence of cleaved-caspase $3^{+}$cells and Annexin $\mathrm{V}^{+}$cells favor to conclude for the presence of radio-induced mitotic catastrophe in these two phenotypes after IR. However, in severe hypoxia $\left(0.2 \% \mathrm{O}_{2}\right), \mathrm{M} 0 \mathrm{M} \Phi$ number remained stable after IR while M1 M $\Phi$ were still decreased. One possible explanation at the decrease in DNA DSBs for M0 $\mathrm{M} \Phi$ at $0.2 \% \mathrm{O}_{2}$ could be that at these low $\mathrm{O}_{2}$ pressure, M0 M $\Phi$ are already engaged toward an M2 phenotype, as already described [12]. For M1 M $\Phi$, the DNA DSBs and the MN profiles confirm that these cells responded to IR in severe hypoxia. Considering the effect of X-rays on M0 MФ $2 \mathrm{~h}$ after treatment and the fact that irradiation is affected by hypoxia, these results would suggest a role of reactive oxygen species (ROS) in the process of radio-induced $\mathrm{M} 0 \mathrm{M} \Phi$ death. Indeed, it was described that IR induced an important production of ROS, almost instantly after treatment, which could contribute to genomic instability [31]. Moreover, hypoxia is known to reduce ROS accumulation [32] which correlates with the decrease in M0 MФ death in oxygen-deprived environment. However, this last phenomenon was not observed in $\mathrm{M} 1 \mathrm{M} \Phi$, suggesting another mechanism involved and more particularly the NO, as M1 MФ are 
known to produce large amount of NO [33]. Indeed, $\mathrm{NO}$ can induce radiosensitization of cells under hypoxic conditions [34-36], including GB cells [37, 38] by enhancing DNA DSBs [38], limiting DNA repair [39] and inducing mitotic catastrophe [37]. This could explain the mechanism involved in M1 radio-induced cell death as we have shown that M1 MФ produced important quantity of NO which decreased in hypoxia, as already published [12], but still superior to the amount observed in M0 and M2 MФ. This effect could correlate with the important M1 MФ death observed in normoxia, which was reduced in hypoxia but still present.

Concerning M2 M $\Phi$, their number was not impacted by radiation and $\mathrm{MN}$ formation was not found $72 \mathrm{~h}$ post-radiation. While M2 M $\Phi$ exhibited DNA DSBs, these data allow us to suggest that M2 MФ are able to faithfully repair DNA DSBs and are more radioresistant to X-rays. The proportion of apoptotic cells in the M2 phenotype was low $(7 \%)$ and no Annexin $\mathrm{V}^{+}$cells were observed. All together, these results suggest that M2 MФ are radioresistant. Interestingly, cell death failed to occur on M2 M $\Phi$ in hypoxic conditions, a situation in which M2 M $\Phi$ are formed to the detriment of M0 and M1 MФ [12]. To understand why M2 MФ are more radioresistant, we performed western blot analyses on P-Erk/panErk and P-Akt/pan-Akt known to be two major players in radioresistance and observed increased expression of P-Erk and P-Akt only in M2 relative to M0 and M1 macrophages (not shown). However, at the present time, we cannot rule out that many other intracellular players could explain this resistance.

Altogether, our in vitro study supports the hypothesis that radiation therapy could increase the proportion of M2 $\mathrm{M} \Phi$ in the tumor. These data concur with the observation of Chiang and colleagues who reported, on animals bearing brain tumors, an increased proportion of the M2 phenotype [17]. Based on our observations, we have made the hypothesis that such a selection may also occur due to the M0 and M1 MФ death, in parallel to a synthesis of polarizing cytokines.

Despite various and vigorous treatments, recurrence always occurs in GB [40]. The presence of glioblastoma stem cells (GSC) has been proposed as a potential explanation for this recurrence [41]. Following our observations, one might propose that the enrichment of the M2 phenotype after radiotherapy could also promote GB recurrence. In accordance with this hypothesis, M2 MФ are known to associate themselves with GSC in hypoxic areas $[42,43]$ to promote tumor development [44]. Moreover, it has been described that the recruitment of myeloid cells following radiation is also responsible for recurrence in different tumors $[45,46]$. In the immediate phase after IR, the number of $M \Phi$ decreased before the recruitment, approximately 20 days post-radiation [13]. This $М \Phi$ repopulation has been, in part, explained by the fact that IR can induce endothelial cell death $[47,48]$ which leads to the development of hypoxia [13, 49] and subsequently an increase in chemokines, such as SDF-1 $[13,14,50]$. The difference between our study and that of Chiang and collaborators [17] and Kioi and collaborators [13] is that they observed an increase in $M \Phi$ migration in parallel to an increase in M2 MФ number after X-rays because their observations were made about 22 days after treatment, when $\mathrm{M} \Phi$ are recruited in GB [13]. In our study, we observed an increase in the proportion of M2 $\mathrm{M} \Phi$ (the phenotype relatively resistant to IR) after X-ray treatment just before $\mathrm{M} \Phi$ recruitment.

The limits of this study are the lack of sensitive markers to differentiate M0, M1 and M2 MФ on mouse brain slides but also the impossibility to perform clonogenic assays (standard colony formation or soft-agar colony formation assays). Another limitation of this study is the use of a single tumor model developed in the mice. It is however important to mention that this is a syngeneic immunoproficient model that also recapitulates various features of the human situation (hypoxia, invasion) [5153]. Despite these caveats, the strength of this study relies on the first demonstration that the three $M \Phi$ phenotypes respond differentially to IR. This has led us to argue that the increase in $\mathrm{M} 2 \mathrm{M} \Phi$ proportion in GB after X-ray treatment is not due to a switch in $M \Phi$ phenotypes but rather to the selective death of M0 and M1 МФ. This pathophysiological process is important to take into account because M2 M $\Phi$ are known to promote tumor development and most recently, studies from the literature indicate that the different $\mathrm{M} \Phi$ phenotypes can induce differential responses of tumor cells to various treatment options and, especially, different chemotherapies [21].

As a conclusion to our study, we have made the assumption that IR could differentially influence the three phenotype of $\mathrm{M} \Phi$ found in tumors. We have demonstrated that the three phenotypes respond to radiation in a phenotype-specific manner. M0 and M1 MФ phenotypes undergo a mitotic death following radiation thereby decreasing cell numbers while M2 M $\Phi$ were radioresistant especially in situations with low $\mathrm{O}_{2}$, areas in which they are mainly enriched $[12,54]$. X-ray radiotherapy can contribute, along with other phenomena, to the increased density of $\mathrm{M} 2 \mathrm{M} \Phi$ in GB.

\section{MATERIALS AND METHODS}

\section{Cell cultures}

The murine GB cell line, GL261[NCI-DCTD (Division of Cancer Treatment and Diagnosis) Repository], was cultured in Roswell Park Memorial Institute media (Sigma-Aldrich) supplemented with $10 \%$ fetal calf serum (Eurobio), $1 \mu \mathrm{g} / \mathrm{ml}$ penicillin/streptomycin (P/S, Sigma-Aldrich) and $2 \mathrm{mM}$ of glutamine (Gln, SigmaAldrich) at $37^{\circ} \mathrm{C}$ in a humidified atmosphere and in mycoplasma free conditions. 
Bone marrow-derived M $\Phi$ were obtained from mice [20-22g, CURB, Univ. Caen, France] and were isolated from femora and tibiae by flushing the bones with $1 \mathrm{ml}$ of Iscove's Modified Dulbecco's Media (IMDM, SigmaAldrich) containing 60\% Fetal Clone II (FCII, Thermo Scientific) and $1 \mu \mathrm{g} / \mathrm{ml} \mathrm{P} / \mathrm{S}$. The marrow was passed through a $70 \mu \mathrm{m}$ strainer and $\mathrm{M} \Phi(\mathrm{M} 0)$ were selected and cultured in IMDM enriched with $15 \%$ FCII, $1 \mu \mathrm{g} / \mathrm{ml} \mathrm{P} / \mathrm{S}, 10$ $\mathrm{ng} / \mathrm{ml}$ recombinant mouse macrophage colony-stimulating factor (M-CSF, Miltenyi Biotec) and $10 \mathrm{ng} / \mathrm{ml}$ recombinant mouse Fms-related tyrosine kinase 3-ligand (Flt3-ligand, Miltenyi Biotec) at $37^{\circ} \mathrm{C}$ in a humid atmosphere. M1 MФ were obtained by culturing cells in $1 \mathrm{~g} / 1$ glucose Dulbecco's Modified Eagle Medium (DMEM, Sigma-Aldrich) supplied with $15 \%$ FCII, $1 \mu \mathrm{g} / \mathrm{ml} \mathrm{P} / \mathrm{S}, 2 \mathrm{mM}$ Gln (Sigma-Aldrich), $100 \mathrm{ng} / \mathrm{ml}$ LPS (Sigma-Aldrich) and 10U/ml recombinant mouse interferon-gamma (IFN- $\gamma$, eBioscience). M2 MФ were obtained by culturing cells with $1 \mathrm{~g} / 1$ glucose DMEM supplemented with 15\% FCII, 1\% P/S, 2mM Gln (SigmaAldrich) and $50 \mathrm{ng} / \mathrm{ml}$ recombinant mouse interleukine 4 (IL4, Miltenyi Biotec).

\section{GB preclinical model}

Tumor models consist of an orthotopic injection of GL261 cells in C57/B16 mice (20-22g, Janvier laboratories). The animal investigations were performed under the current European directive (2010/63/EU). The license to investigate was given to SV (14-55) in authorized housing and laboratories (B14118001) and with the permission of the regional committee on animal ethics (N/04-01-13/04/01-16). Mice were operated under anaesthesia (induction in 5\% and maintenance in $2 \%$ of isoflurane in $70 \% \mathrm{NO}_{2} / 30 \% \mathrm{O}_{2}$ ) and GL261 cells were injected $\left[1.10^{5}\right.$ cells in $3 \mu \mathrm{l}$ in $2 \mathrm{mM} \mathrm{Gln} /$ phosphate buffer saline $(\mathrm{PBS})]$ in the right caudate-putamen.

\section{Hypoxic cell treatment}

Normoxia $\left(20 \% \mathrm{O}_{2}\right)$ cells were cultured in a humidified $5 \% \mathrm{CO}_{2} /$ air atmosphere. Moderate $\left(1 \% \mathrm{O}_{2}\right.$, the $\mathrm{O}_{2}$ level commonly found in GB) [22] and severe $\left(0.2 \% \mathrm{O}_{2}\right.$, the $\mathrm{O}_{2}$ level found around necrotic areas of GB) hypoxic cells were cultured in a humidified $5 \% \mathrm{CO}_{2}$ /balance $\mathrm{N}_{2}$ gas mixture in a hypoxic chamber (Invivo2 500, Ruskinn, Awel) at $37^{\circ} \mathrm{C}$. For radiation treatment, M0 MФ were cultured either in normoxia or in hypoxia $6 \mathrm{~h}$ before radiation. M1 and M2 MФ were activated for $24 \mathrm{~h}$ and then cultured in normoxia or hypoxia $6 \mathrm{~h}$ before radiation with their respective conditioning media. The hypoxic culture medium was equilibrated for $30 \mathrm{~min}$ with the gas mixture contained in the hypoxia chamber before add it to cell cultures.

\section{Radiation treatments}

All radiation experiments were performed on the XRad225Cx (PXi, CYCERON platform).
For in vivo experiments, the radiation of ipsilateral hemisphere was realized seven days after the implantation of GB cells (tumor volume around $10 \mathrm{~mm}^{3}$ ). Mice were anaesthetized as described above and irradiated thrice with $4 \mathrm{~Gy}$ dose every two days at a dose rate of $3.3 \mathrm{~Gy} / \mathrm{min}$. The animals were sacrificed 15 days after implantation of tumor cells for the non-irradiated animals and 7 days and 20 days after the first irradiation for the irradiated animals (Figure 1). The tumor volume was evaluated by a T2w MRI scan (7T MRI, Bruker, CYCERON Imaging platform).

For in vitro experiments, cells were exposed at room temperature to X-ray to a unique dose of $2 \mathrm{~Gy}$ (or $8 \mathrm{~Gy}$ ) at a dose rate of $2 \mathrm{~Gy} / \mathrm{min}$. After radiation, cells were maintained under normoxic or hypoxic conditions until the end of the experiment.

\section{Immunohistochemistry}

At the end of the protocol, mice were deeply anaesthetized and were transcardially perfused with a $0.2 \mathrm{M}$ phosphate buffer (PB)/4\% paraformaldehyde (PFA, Sigma-Aldrich). Brains were removed and placed in $30 \%$ sucrose for $48 \mathrm{~h}$ and $30 \mu \mathrm{m}$ thick freezing microtome sections were realized. Slices were blocked with PBS, $0.5 \%$ Triton, $3 \%$ bovine serum albumin (BSA, SigmaAldrich) for $2 \mathrm{~h}$ and then incubated overnight with antiCD68 (1/800, Abcam, ab53444) and anti-CD206 (1/1000, Abcam, ab64693) antibodies in PBS, $0.5 \%$ Triton, $1 \%$ $\mathrm{BSA}$ at $4^{\circ} \mathrm{C}$. Sections were then incubated with an Alexa555-conjugated anti-rat (1/200, Invitrogen, A18744) or an Alexa-488-conjugated anti-rabbit (1/200, Invitrogen, 10424752 ) as secondary antibodies in PBS, $0.5 \%$ Triton, $1 \%$ BSA containing Hoechst $33342(10 \mu \mathrm{g} / \mathrm{ml}$, SigmaAldrich).

\section{Immunocytochemistry}

MФ were fixed with a $0.2 \mathrm{M} \mathrm{PB} / 4 \%$ PFA solution. Cells were blocked with PBS, $0.1 \%$ Tween, 3\% BSA for $30 \mathrm{~min}$ and the cells were firstly incubated overnight at $4^{\circ} \mathrm{C}$ with the primary antibody in PBS $0.1 \%$ Tween, $1 \%$ $\mathrm{BSA}$ at $4^{\circ} \mathrm{C}$. The following primary antibodies were used: phosphorylated histone $\mathrm{H} 2 \mathrm{AX}$ (ser139) $(\gamma \mathrm{H} 2 \mathrm{AX} ; 1 / 200$; Cell Signalling Technology, 2577S) and cleaved-caspase-3 (1/600; Cell Signaling Technology, 9661S). $\gamma \mathrm{H} 2 \mathrm{AX}$ and cleaved-caspase- 3 are sensitive markers of DNA doublestrand breaks [55] and apoptosis, respectively. Cells then were incubated with an Alexa-555-conjugated anti-rabbit secondary antibody (1/200; Invitrogen, A31572) and Hoechst $33342(10 \mu \mathrm{g} / \mathrm{ml})$ in PBS $0.1 \%$ Tween, 1\% BSA for $2 \mathrm{~h}$ at room temperature.

\section{Cytotoxic assay}

The effect of radiation on cell survival was measured by manually counting the cell number $2 \mathrm{~h}, 24 \mathrm{~h}$ and $72 \mathrm{~h}$ 
after radiation. М $\Phi$ were fixed as mentioned above and cell nuclei were stained with Hoechst $33342(10 \mu \mathrm{g} / \mathrm{ml})$.

\section{Image analysis}

Images were acquired thanks to the time-lapse microscope (DMi8 S imaging system, Leitz LEICA) and then analyzed by ImageJ software (http://imagej. nih.gov/ij/). For immunohistochemistry, $\mathrm{M} \Phi$ density was determined as the number of positive area for CD68 divided by the total tumor area using an automatic thresholding. The percentage of M $2 \mathrm{M} \Phi$ was determined by a manual counting of the number of cells that expressed both CD206 (M2 MФ) and CD68 (MФ). For immunocytochemistry, the number of cells was manually counted. For $\gamma \mathrm{H} 2 \mathrm{AX}$ immunostaining, cells with at least 10 foci in nucleus were considered as positive. The percentage of $\gamma \mathrm{H} 2 \mathrm{AX}^{+}$cells was determined by the number of $\gamma \mathrm{H} 2 \mathrm{AX}$ compared to the total number of cells (Hoechst 33342). The percentage of cleaved-caspase $3^{+}$ cells was determined by the number of cleaved-caspase $3^{+}$cells compared to the total number of cells (Hoechst 33342). The presence of micronuclei (MN, indicative of genomic instability followed by mitotic catastrophe [56]) was assessed by Hoechst 33342 staining and a cell with at least one $\mathrm{MN}$ was considered positive.

\section{Cell cycle analysis}

The cell cycle of $M \Phi$ was studied by flow cytometry with the DNA-prep reagents kit according to manufacturer's instructions (Beckman Coulter SAS, France). Propidium iodide staining was analyzed by the Gallios $^{\mathrm{TM}}$ flow cytometer (Beckman Coulter SAS, France) with 20000 events per determination. The analysis and determination of the cell distribution in each phase of the cell cycle was achieved based on the Kaluza ${ }^{\circledR}$ Flow Analysis software (Beckman Coulter SAS, France).

\section{Propidium iodide (PI)/AnnexinV analysis}

This experiment was performed using Annexin V-FITC Kit (Beckman Coulter), following the manufacturer's protocol. Briefly, cell samples (M0, M1 and M2 macrophages irradiated or not) were washed with cold PBS and cell pellet was resuspended in 1X binding buffer and immediately kept on ice. Annexin V-FITC solution and Propidium Iodide (IP) were added and incubated for 15 minutes on ice in the dark. Subsequently, cells were analyzed by flow cytometry, using Gallios ${ }^{\mathrm{TM}}$ flow cytometer and at least 20000 events were collected per sample. Data was analyzed using Kaluza ${ }^{\circledR}$ Flow Analysis software.

\section{Determination of nitric oxide (NO) production}

NO measurement in the supernatant of $М \Phi$ cultures was performed by the Griess reaction [57]. Each sample was assayed in duplicate, the absorbance was measured at $540 \mathrm{~nm}$ and the NO concentration was determined with sodium nitrite as a standard.

\section{Determination of Arg1 activity}

Arg1 activity was determined by a standard colorimetric method in cell lysates as published [57]. Each sample was assayed in duplicate, the absorbance was measured at $540 \mathrm{~nm}$ and urea production was determined with urea as the standard.

\section{Online supplementary materials}

Supplementary Materials about proliferation assay and cell debris analyses are available in the online version of the paper.

\section{Statistical analyses}

Data are represented by the mean \pm standard deviation (SD), the circles representing results of individual experiment. Statistical analyses were performed with the JMP ${ }^{\circledR}$ program (SAS institute, USA) and, unless otherwise stated, significances were calculated by the Tukey's HSD test after significant ANOVAs.

\section{Abbreviations}

Arg1: arginase 1; DSB: double strand breaks; GB: glioblastoma; GSC: glioblastoma stem cells; iNOS: inducible nitric oxide synthase; IR: ionizing radiation; $\mathrm{M \Phi :} \mathrm{macrophages;} \mathrm{MN}$ : micronuclei; NO: nitric oxide; $\mathrm{O}_{2}$ : oxygen; PI: propidium iodide; SDF-1: stromal cell derived factor 1; TAM: tumor associated macrophages.

\section{ACKNOWLEDGMENTS}

The authors wish to thank Eric T. MacKenzie for his English expertise on this article and the SFR ICORE (Intéraction Cellules-Organismes-Environnement) platform localized in Caen (France) for the access to the materials used to perform the flow cytometry analyses.

\section{CONFLICTS OF INTEREST}

No potential conflicts of interest were disclosed.

\section{FINANCIAL SUPPORT}

Centre National de la Recherche Scientifique (CNRS), the Université de Caen-Normandie (UNICAEN), the French Ministère de l'Enseignement Supérieur et de la Recherche (MESR), the Conseil Régional de BasseNormandie (CRBN), the Advanced Resource Center for Hadrontherapy in Europe (Archade), the Fédération 
pour la Recherche sur le Cerveau par l'opération Rotary

"Espoir en tête » (FRC) and the French National Agency for Research called "Investissements d'Avenir" ANR-11LABEX-0018-01 ; ANR-10-EQPX-1401 and ANR-11INSB-0007.

\section{REFERENCES}

1. Ostrom QT, Gittleman H, Fulop J, Liu M, Blanda R, Kromer C, Wolinsky Y, Kruchko C, Barnholtz-Sloan JS. CBTRUS statistical report: primary brain and central nervous system tumors diagnosed in the United States in 2008-2012. Neuro Oncol. 2015; 17:iv1-iv62.

2. Stupp R, Mason WP, van den Bent MJ, Weller M, Fisher B, Taphoorn MJB, Belanger K, Brandes AA, Marosi C, Bogdahn U, Curschmann J, Janzer RC, Ludwin SK, et al. Radiotherapy plus concomitant and adjuvant temozolomide for glioblastoma. N Engl J Med. 2005; 352:987-96.

3. Stupp R, Hegi ME, Mason WP, van den Bent MJ, Taphoorn MJ, Janzer RC, Ludwin SK, Allgeier A, Fisher B, Belanger K, Hau P, Brandes AA, Gijtenbeek J, et al. Effects of radiotherapy with concomitant and adjuvant temozolomide versus radiotherapy alone on survival in glioblastoma in a randomised phase III study: 5-year analysis of the EORTCNCIC trial. Lancet Oncol. 2009; 10:459-66.

4. Charles NA, Holland EC, Gilbertson R, Glass R, Kettenmann $\mathrm{H}$. The brain tumor microenvironment. Glia. 2011; 59:1169-80.

5. Hussain SF, Yang D, Suki D, Aldape K, Grimm E, Heimberger AB. The role of human glioma-infiltrating microglia/macrophages in mediating antitumor immune responses. Neuro Oncol. 2006; 8:261-79.

6. Wynn TA, Chawla A, Pollard JW. Macrophage biology in development, homeostasis and disease. Nature. 2013; 496:445-55.

7. Rossi ML, Hughes JT, Esiri MM, Coakham HB, Brownell DB. Immunohistological study of mononuclear cell infiltrate in malignant gliomas. Acta Neuropathol. 1987; 74:269-77.

8. Lu-Emerson C, Snuderl M, Kirkpatrick ND, Goveia J, Davidson C, Huang Y, Riedemann L, Taylor J, Ivy P, Duda DG, Ancukiewicz M, Plotkin SR, Chi AS, et al. Increase in tumor-associated macrophages after antiangiogenic therapy is associated with poor survival among patients with recurrent glioblastoma. Neuro Oncol. 2013; 15:1079-87.

9. Mantovani A, Sica A. Macrophages, innate immunity and cancer: balance, tolerance, and diversity. Curr Opin Immunol. 2010; 22:231-7.

10. Kennedy BC, Showers CR, Anderson DE, Anderson L, Canoll P, Bruce JN, Anderson RC. Tumor-associated macrophages in glioma: friend or foe? J Oncol. 2013; 2013:486912.
11. Chang CI, Liao JC, Kuo L. Macrophage arginase promotes tumor cell growth and suppresses nitric oxide-mediated tumor cytotoxicity. Cancer Res. 2001; 61:1100-6.

12. Leblond MM, Gérault AN, Corroyer-Dulmont A, MacKenzie ET, Petit E, Bernaudin M, Valable S. Hypoxia induces macrophage polarization and re-education toward an M2 phenotype in U87 and U251 glioblastoma models. Oncoimmunology. 2015; 5:e1056442.

13. Kioi M, Vogel H, Schultz G, Hoffman RM, Harsh GR, Brown JM. Inhibition of vasculogenesis, but not angiogenesis, prevents the recurrence of glioblastoma after irradiation in mice. J Clin Invest. 2010; 120:694-705.

14. Wang SC, Yu CF, Hong JH, Tsai CS, Chiang CS. Radiation therapy-induced tumor invasiveness is associated with SDF1-regulated macrophage mobilization and vasculogenesis. PLoS One. 2013; 8:e69182.

15. Xu J, Escamilla J, Mok S, David J, Priceman S, West B, Bollag G, McBride W, Wu L. CSF1R signaling blockade stanches tumor-infiltrating myeloid cells and improves the efficacy of radiotherapy in prostate cancer. Cancer Res. 2013; 73:2782-94.

16. Coates PJ, Rundle JK, Lorimore SA, Wright EG. Indirect macrophage responses to ionizing radiation: implications for genotype-dependent bystander signaling. Cancer Res. 2008; 68:450-6.

17. Chiang CS, Fu SY, Wang SC, Yu CF, Chen FH, Lin $\mathrm{CM}$, Hong JH. Irradiation promotes an M2 macrophage phenotype in tumor hypoxia. Front Oncol. 2012; 2:89.

18. Dong C, He M, Ren R, Xie Y, Yuan D, Dang B, Li W, Shao C. Role of the MAPK pathway in the observed bystander effect in lymphocytes co-cultured with macrophages irradiated with $\gamma$-rays or carbon ions. Life Sci. 2015; 127:19-25.

19. Conrad S, Ritter S, Fournier C, Nixdorff K. Differential effects of irradiation with carbon ions and x-rays on macrophage function. J Radiat Res. 2009; 50:223-31.

20. Narita T, Aoyama H, Hirata $K$, Onodera S, Shiga T, Kobayashi H, Murata J, Terasaka S, Tanaka S, Houkin K. Reoxygenation of glioblastoma multiforme treated with fractionated radiotherapy concomitant with temozolomide: changes defined by $18 \mathrm{~F}$-fluoromisonidazole positron emission tomography: two case reports. Jpn J Clin Oncol. 2012; 42:120-3.

21. De Palma M, Lewis CE. Macrophage regulation of tumor responses to anticancer therapies. Cancer Cell. 2013; 23:277-86

22. Hou H, Krishnamurthy Nemani V, Du G, Montano R, Song R, Gimi B, Swartz HM, Eastman A, Khan N. Monitoring oxygen levels in orthotopic human glioma xenograft following carbogen inhalation and chemotherapy by implantable resonator-based oximetry. Int J Cancer. 2014; 136:1688-96. 
23. Russo A, Pacchierotti F, Cimini D, Ganem NJ, Genescà A, Natarajan AT, Pavanello S, Valle G, Degrassi F. Genomic instability: crossing pathways at the origin of structural and numerical chromosome changes. Environ Mol Mutagen. 2015; 56:563-80.

24. Prosniak M, Harshyne LA, Andrews DW, Kenyon LC, Bedelbaeva K, Apanasovich TV, Heber-Katz E, Curtis MT, Cotzia P, Hooper DC. Glioma grade is associated with the accumulation and activity of cells bearing M2 monocyte markers. Clin Cancer Res. 2013; 19:3776-86.

25. Klug F, Prakash H, Huber PE, Seibel T, Bender N, Halama N, Pfirschke C, Voss RH, Timke C, Umansky L, Klapproth K, Schäkel K, Garbi N, et al. Low-dose irradiation programs macrophage differentiation to an iNOS+/M1 phenotype that orchestrates effective T cell immunotherapy. Cancer Cell. 2013; 24:589-602.

26. Xiao L, Liu W, Li J, Xie Y, He M, Fu J, Jin W, Shao C. Irradiated U937 cells trigger inflammatory bystander responses in human umbilical vein endothelial cells through the p38 pathway. Radiat Res. 2014; 182:111-21.

27. Prakash H, Klug F, Nadella V, Mazumdar V, Winnenthal HS, Umansky L. Low doses of gamma irradiation (LDR) potentially modifies immunosuppressive tumor microenvironment by retuning tumor-associated macrophages (TAM): lesson from insulinoma. Carcinogenesis. 2016; 37:301-13.

28. Ridnour LA, Cheng RY, Weiss JM, Kaur S, Soto-Pantoja DR, Basudhar D, Heinecke JL, Stewart CA, DeGraff W, Sowers AL, Thetford A, Kesarwala AH, Roberts DD, et al. NOS inhibition modulates immune polarization and improves radiation-induced tumor growth delay. Cancer Res. 2015; 75:2788-99.

29. Pinto AT, Pinto ML, Cardoso AP, Monteiro C, Pinto MT, Maia AF, Castro P, Figueira R, Monteiro A, Marques M, Mareel M, Gomes Dos Santos S, Seruca R, et al. Ionizing radiation modulates human macrophages towards a proinflammatory phenotype preserving their pro-invasive and pro-angiogenic capacities. Sci Rep. 2016; 6:18765.

30. Wunderlich R, Ernst A, Rödel F, Fietkau R, Ott O, Lauber K, Frey B, Gaipl US. Low and moderate doses of ionizing radiation up to 2 Gy modulate transmigration and chemotaxis of activated macrophages, provoke an antiinflammatory cytokine milieu, but do not impact upon viability and phagocytic function. Clin Exp Immunol. 2015; 179:50-61.

31. Dayal R, Singh A, Pandey A, Mishra KP. Reactive oxygen species as mediator of tumor radiosensitivity. J Cancer Res Ther. 2014; 10:811-8.

32. Halliwell B, Gutteridge J. Free Radicals in Biology and Medicine. 4th ed. Oxford: Oxford University Press; 2007.

33. Mantovani A, Sozzani S, Locati M, Allavena P, Sica A. Macrophage polarization: tumor-associated macrophages as a paradigm for polarized M2 mononuclear phagocytes. Trends Immunol. 2002; 23:549-55.
34. Howard-Flanders P. Effect of nitric oxide on the radiosensitivity of bacteria. Nature. 1957; 180:1191-2.

35. Jiang H, De Ridder M, Verovski VN, Sonveaux P, Jordan BF, Law K, Monsaert C, Van den Berge DL, Verellen D, Feron O, Gallez B, Storme GA. Activated macrophages as a novel determinant of tumor cell radioresponse: the role of nitric oxide-mediated inhibition of cellular respiration and oxygen sparing. Int J Radiat Oncol Biol Phys. 2010; 76:1520-7.

36. Yakovlev VA. Role of nitric oxide in the radiation-induced bystander effect. Redox Biol. 2015; 6:396-400.

37. Günzle J, Osterberg N, Saavedra JE, Weyerbrock A. Nitric oxide released from JS-K induces cell death by mitotic catastrophe as part of necrosis in glioblastoma multiforme. Cell Death Dis. 2016; 7:e2349.

38. Heckler M, Osterberg N, Guenzle J, Thiede-Stan NK, Reichardt W, Weidensteiner C, Saavedra JE, Weyerbrock A. The nitric oxide donor JS-K sensitizes U87 glioma cells to repetitive irradiation. Tumor Biol. 2017; 39:101042831770392.

39. Lomax ME, Folkes LK, O’Neill P. Biological consequences of radiation-induced DNA damage: relevance to radiotherapy. Clin Oncol. 2013; 25:578-85.

40. Steffens R, Semrau S, Lahmer G, Putz F, Lettmaier S, Eyüpoglu I, Buchfelder M, Fietkau R. Recurrent glioblastoma: who receives tumor specific treatment and how often? J Neurooncol. 2016; 128:85-92.

41. Jackson M, Hassiotou F, Nowak A. Glioblastoma stemlike cells: at the root of tumor recurrence and a therapeutic target. Carcinogenesis. 2015; 36:177-85.

42. Pistollato F, Abbadi S, Rampazzo E, Persano L, Della Puppa A, Frasson C, Sarto E, Scienza R, D'Avella D, Basso G. Intratumoral hypoxic gradient drives stem cells distribution and MGMT expression in glioblastoma. Stem Cells. 2010; 28:851-62.

43. Tafani M, Di Vito M, Frati A, Pellegrini L, De Santis E, Sette G, Eramo A, Sale P, Mari E, Santoro A, Raco A, Salvati M, De Maria R, et al. Pro-inflammatory gene expression in solid glioblastoma microenvironment and in hypoxic stem cells from human glioblastoma. $\mathrm{J}$ Neuroinflammation. 2011; 8:32.

44. Zhou W, Ke SQ, Huang Z, Flavahan W, Fang X, Paul J, Wu L, Sloan AE, McLendon RE, Li X, Rich JN, Bao S. Periostin secreted by glioblastoma stem cells recruits M2 tumour-associated macrophages and promotes malignant growth. Nat Cell Biol. 2015; 17:170-82.

45. Liu SC, Alomran R, Chernikova SB, Lartey F, Stafford J, Jang T, Merchant M, Zboralski D, Zöllner S, Kruschinski A, Klussmann S, Recht L, Brown JM. Blockade of SDF-1 after irradiation inhibits tumor recurrences of autochthonous brain tumors in rats. Neuro Oncol. 2014; 16:21-8.

46. Okubo M, Kioi M, Nakashima H, Sugiura K, Mitsudo K, Aoki I, Taniguchi H, Tohnai I. M2-polarized macrophages 
contribute to neovasculogenesis, leading to relapse of oral cancer following radiation. Sci Rep. 2016; 6:27548.

47. Bonnaud S, Niaudet C, Pottier G, Gaugler MH, Millour J, Barbet J, Sabatier L, Paris F. Sphingosine-1-phosphate protects proliferating endothelial cells from ceramideinduced apoptosis but not from DNA damage-induced mitotic death. Cancer Res. 2007; 67:1803-11.

48. Ungvari Z, Podlutsky A, Sosnowska D, Tucsek Z, Toth P, Deak F, Gautam T, Csiszar A, Sonntag WE. Ionizing radiation promotes the acquisition of a senescenceassociated secretory phenotype and impairs angiogenic capacity in cerebromicrovascular endothelial cells: role of increased DNA damage and decreased DNA repair capacity in microvascular radiosens. J Gerontol A Biol Sci Med Sci. 2013; 68:1443-57.

49. Warrington JP, Csiszar A, Johnson DA, Herman TS, Ahmad S, Lee YW, Sonntag WE. Cerebral microvascular rarefaction induced by whole brain radiation is reversible by systemic hypoxia in mice. Am J Physiol Heart Circ Physiol. 2011; 300:H736-44.

50. Zagzag D, Esencay M, Mendez O, Yee H, Smirnova I, Huang Y, Chiriboga L, Lukyanov E, Liu M, Newcomb EW. Hypoxia- and vascular endothelial growth factorinduced stromal cell-derived factor- $1 \alpha / \mathrm{CXCR} 4$ expression in glioblastomas: one plausible explanation of Scherer's structures. Am J Pathol. 2008; 173:545-60.

51. Newcomb EW, Demaria S, Lukyanov Y, Shao Y, Schnee T, Kawashima N, Lan L, Dewyngaert JK, Zagzag D, McBride $\mathrm{WH}$, Formenti SC. The combination of ionizing radiation and peripheral vaccination produces long-term survival of mice bearing established invasive GL261 gliomas. Clin Cancer Res. 2006; 12:4730-7.

52. Doblas S, He T, Saunders D, Hoyle J, Smith N, Pye Q, Lerner M, Jensen RL, Towner RA. In vivo characterization of several rodent glioma models by $1 \mathrm{H}$ MRS. NMR Biomed. 2012; 25:685-94.

53. Bürgi S, Seuwen A, Keist R, Vom Berg J, Grandjean J, Rudin M. in vivo imaging of hypoxia-inducible factor regulation in a subcutaneous and orthotopic GL261 glioma tumor model using a reporter gene assay. Mol Imaging. $2014 ; 13: 1-11$.

54. Movahedi K, Laoui D, Gysemans C, Baeten M, Stangé G, Van den Bossche J, Mack M, Pipeleers D, In't Veld P, De Baetselier P, Van Ginderachter JA. Different tumor microenvironments contain functionally distinct subsets of macrophages derived from Ly6C(high) monocytes. Cancer Res. 2010; 70:5728-39.

55. Ivashkevich A, Redon CE, Nakamura AJ, Martin RF, Martin OA. Use of the $\gamma$-H2AX assay to monitor DNA damage and repair in translational cancer research. Cancer Lett. 2012; 327:123-33.

56. Iarmarcovai G, Bonassi S, Botta A, Baan RA, Orsière T. Genetic polymorphisms and micronucleus formation: a review of the literature. Mutat Res. 2008; 658:215-33.

57. Reiner NE, editor. Macrophages and Dendritic Cells: Methods and Protocols. New York, NY: Humana Press; 2009. 